\title{
HUNGARIAN LICHENOLOGISTS - A 60TH BIRTHDAY TRIBUTE
}

\author{
Nóra VARgA ${ }^{1 *}$, Dániel Pif Kó ${ }^{2}$, Sergij Y. KondratyuK ${ }^{3}$, \\ Ingvar KäRNEFELT ${ }^{4}$ and Arne THELL ${ }^{4}$ \\ ${ }^{1}$ Institute of Ecology and Botany, Centre for Ecological Research, \\ H-2163 Vácrátót, Alkotmány u. 2-4, Hungary; *arga.nora@okologia.mta.hu \\ ${ }^{2}$ Department of Botany, Hungarian Natural History Museum, H-1431 Budapest, Pf. 137, Hungary \\ ${ }^{3}$ M. H. Kholodny Institute of Botany, National Academy of Sciences of Ukraine, \\ Tereshchenkivska str. 2, 01004 Kiev, Ukraine \\ ${ }^{4}$ Biological Museum, Lund University, Box 117, 22100 Lund, Sweden
}

Varga, N., Pifkó, D., Kondratyuk, S. Y., Kärnefelt, I. \& Thell, A. (2019): Hungarian lichenologists a 60th birthday tribute. - Studia bot. hung. 50(2): 261-292.

\begin{abstract}
Edit Farkas and László Lőkös are internationally well known and respected Hungarian lichenologists. They did their best to maintain and to develop several aspects of the Hungarian lichenology, including biodiversity research on lichen-forming and lichenicolous fungi, taxonomic revisions based on morphological, chemical and molecular methods, ecological, ecophysiological and conservation biological research, as well as investigations on history of science and bibliographical compilations. Hungarian lichen herbaria were enriched considerably by their various Hungarian collections as well as collections from tropical, temperate Asian and Balkan areas. We shortly overview their scientific career and results publishing in more than 100 scientific papers, and similar amount of scientific and popular presentations. As key persons in traditional Hungarian lichenology, their keen and precise way of research might serve as a good example to their students and colleagues.
\end{abstract}

Key words: lichenology, biography, birthday tribute, science history

\section{INTRODUCTION}

Edit Farkas and László Lökös, both Hungarian lichenologists, celebrated their 60th birthday this year, in 2019. These two people, these two names are inseparable from lichenology and known worldwide. They are spouse and colleagues to each other, who are committed to biology, within that to lichenology in the early stage of their carrier.

Edit Farkas has been working at the Institute of Ecology and Botany, Centre for Ecological Research in Vácrátót (the institute had several names before) as a scientific advisor, while László Lőkös has been working at the Botanical Department of the Hungarian Natural History Museum, Budapest, as the curator of the lichen herbarium.

They have two grown-up children, Dániel and Laura. 
During the university they were influenced by several famous professors, such as Pál Juhász-Nagy, Sándor Koch, Tibor Simon, Gábor Vida and others. They happily visited several additional special courses in various fields of biology as students and took part in the excursions organised by the Department of Plant Taxonomy and Ecology of the Eötvös Loránd University in Budapest. Both of them became inspired to learn about lichens together at the Department of Botany of the Hungarian Natural History Museum, near the senior scientist Klára Verseghy, who was the supervisor of their MSc theses.

The most exciting event was their first international conference (the 14th International Botanical Congress) held in 1987 in Berlin, on which they took part. This was naturally a great opportunity to meet with well-known international scientists, such as Mason E. Hale, Aino Henssen, Josef Poelt, Thomas H. Nash and Mark Seaward to mention a few of the most famous ones. Edit Farkas had an oral presentation: "Importance of the asexual reproductive organs in foliicolous lichen taxonomy" to with she received the DAAD fellowship for young botanists. The IBC 14, must have made a great impression on both Edit and László and caused their choice for future career in lichenology.

The elder author (IK) of this paper also visited the Berlin meeting and remember the young couple very well, particularly from the IAL (International Association for Lichenology) dinner where they celebrated Mason Hale in a special written song ("Ten green Parmelias hanging on the wall...") together with some colleagues (Mark Seaward, Brian Coppins). This was the first time they met and since then they have been seen at many international meetings.

Already at the beginning of their career they have recognised the importance of the international relationships and collaboration of lichenologists from the surrounding countries. At that time to get the newest literature and herbarium specimens was not as easy as nowadays. As young scientists they were not only influenced by more experienced lichenologists, to mention some of the most famous, like the Austrian Josef Poelt (Fig. 1) and the Bohemian Antonín Vězda (Fig. 2), but they had contact with Dagmar Triebel, Rosemarie Honegger, Ivan Pišút, and many others.

They started to work on lichen mapping in the context of bioindication of air quality by lichens parallel with floristical investigations of several areas of Hungary. Edit has a main interest on tropical foliicolous lichens and lichen secondary metabolites, and László focuses mostly on floristical works in countries from the Balkan Peninsula and South Korea, but both of them are working on the lichen-forming and lichenicolous fungi of Hungary, the Carpathian Basin, and several parts of the Carpathians together with their colleagues from Hungary and neighbouring countries (Fig. 3), e.g. A. Guttová, E. Lisická, A. Lackovičová, K. Bartók, F. Crişan and others. 


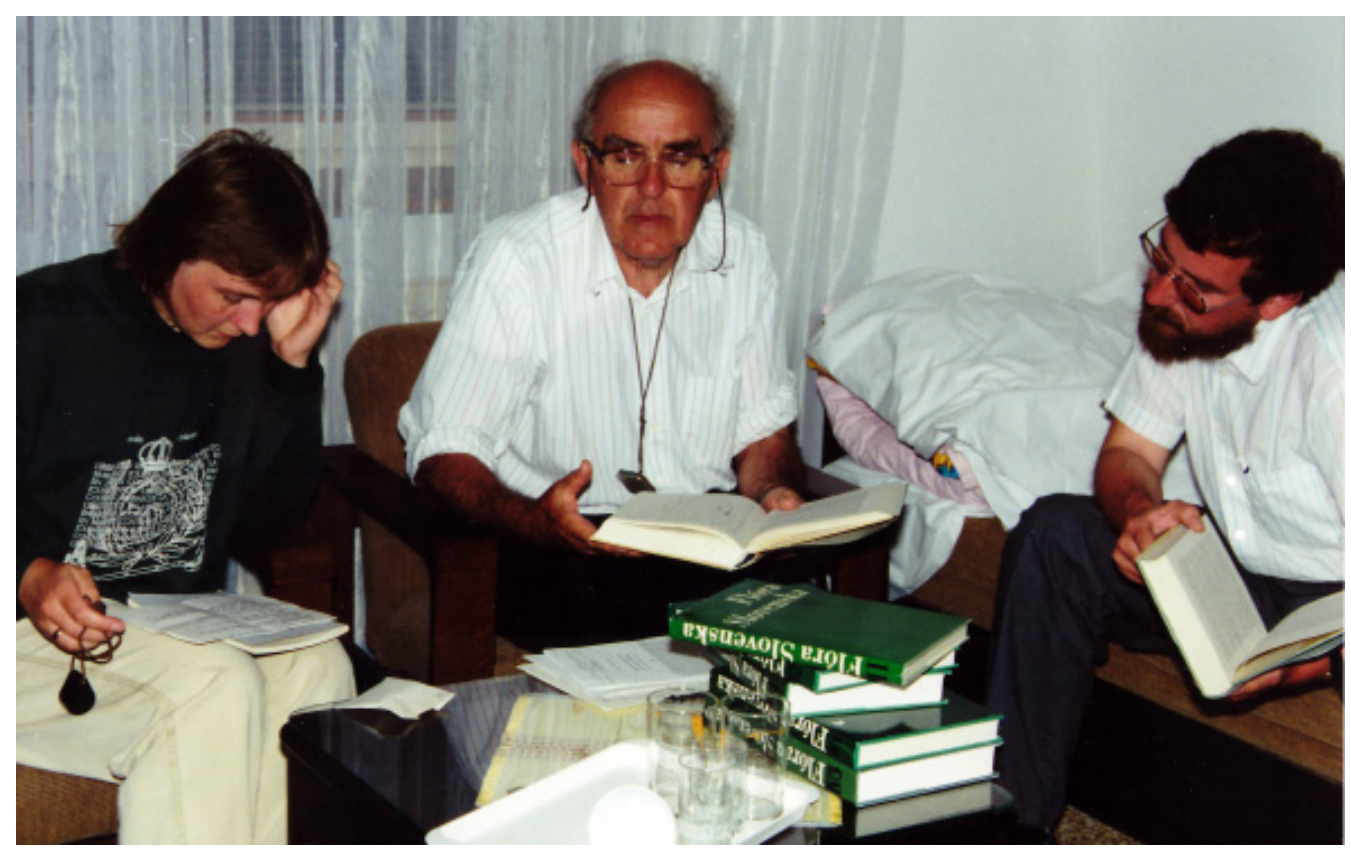

Fig. 1. Edit Farkas, Josef Poelt, and Peter Scholz on a BLS meeting in Slovakia in 1993.

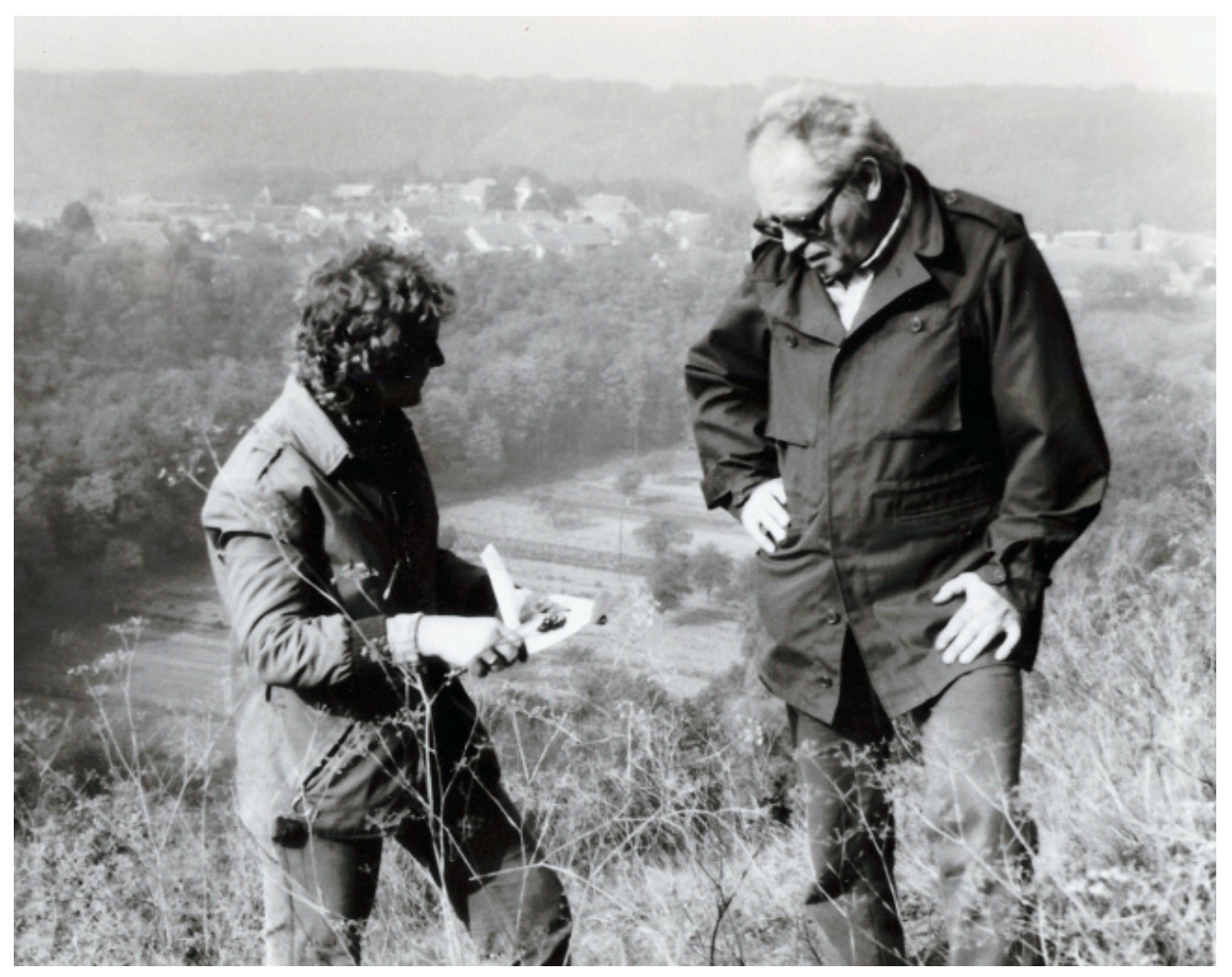

Fig. 2. Edit Farkas with Antonín Vězda in the field in Rokytna in 1983. 


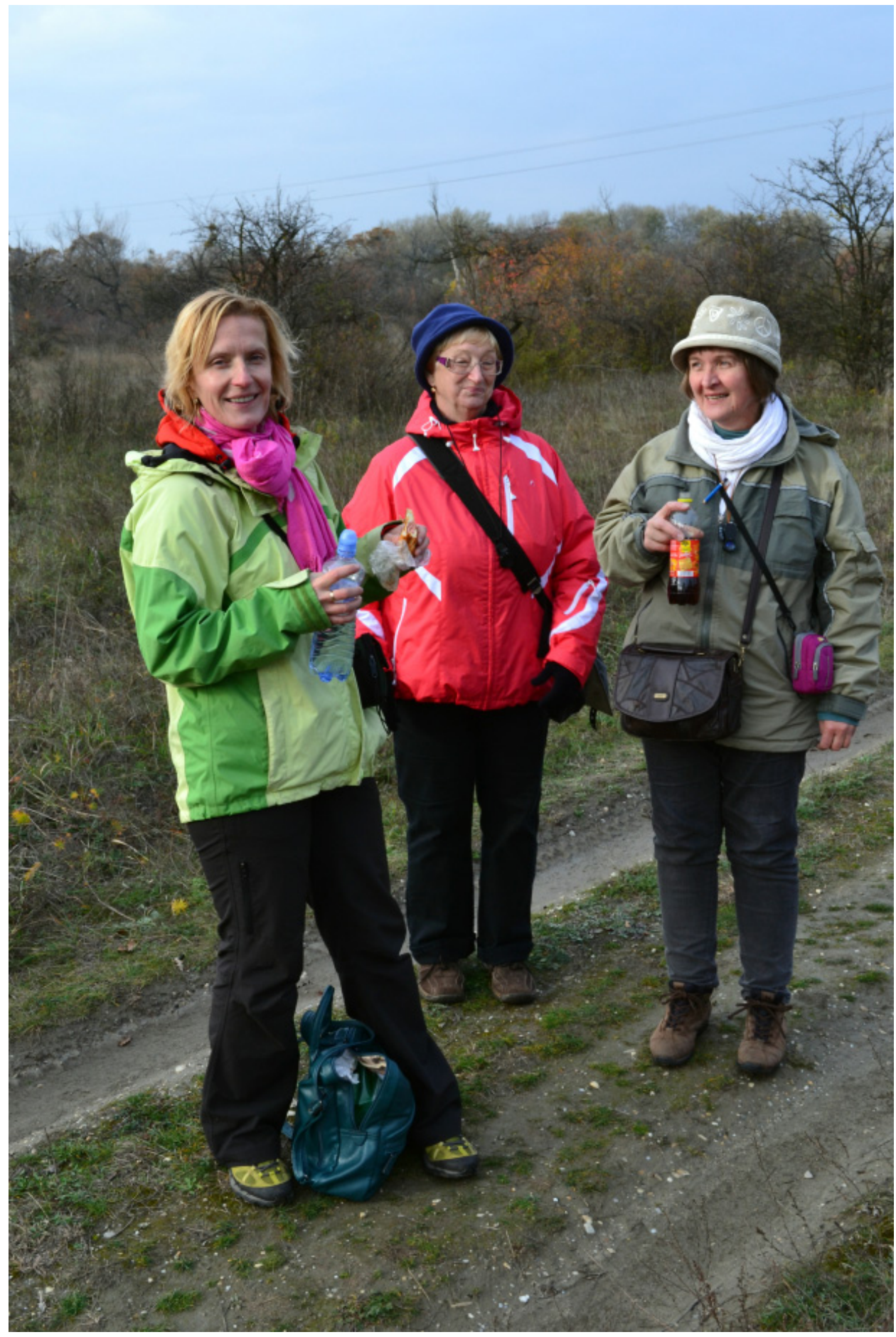

Fig. 3. Kopácsky ostrov, Bratislava, November 2013. Anna Guttová, Anna Lackovičová, and Edit Farkas (photo: N. Varga). 
In the framework of the Royal Society Fellowship grant Edit received in 1992 they could spend a year in the Natural History Museum in London (Fig. 4). The scientific program was mainly organised and supervised by David J. Galloway. During their stay in NHM they also got to know Peter James, Jack Laundon, William O. Purvis and Pat(ricia) A. Wolseley. Together with Begoña Aguirre-Hudson they published new results about the pyrenolichens of Hungary (AGUIRRE-HUDSON et al. 2002) and the Carpathian Basin (AgUiRRE-Hudson et al. 2005).

They always took special attention of biodiversity and nature protection. For this reason the first lichen red list in Hungary was compiled in 1997 (Lö Kös \& Tóth 1997). Following some early proposals (FARKAs et al. 1999a, FARKAS \& LöKös 2003, 2004) finally five lichen species gained protection according to law "23/2005. (VIII.31) KVVM" in 2005. Since then 17 lichen species have gained legal protection in Hungary (FAR KAS \& LöKös 2007).

In 2016 they were honoured by the 'Boros Ádám Award', which is one of the most prestigious acknowledgements among botanists in Hungary. During his speech, Prof. Attila Borhidi emphasised that the pair made outstanding and

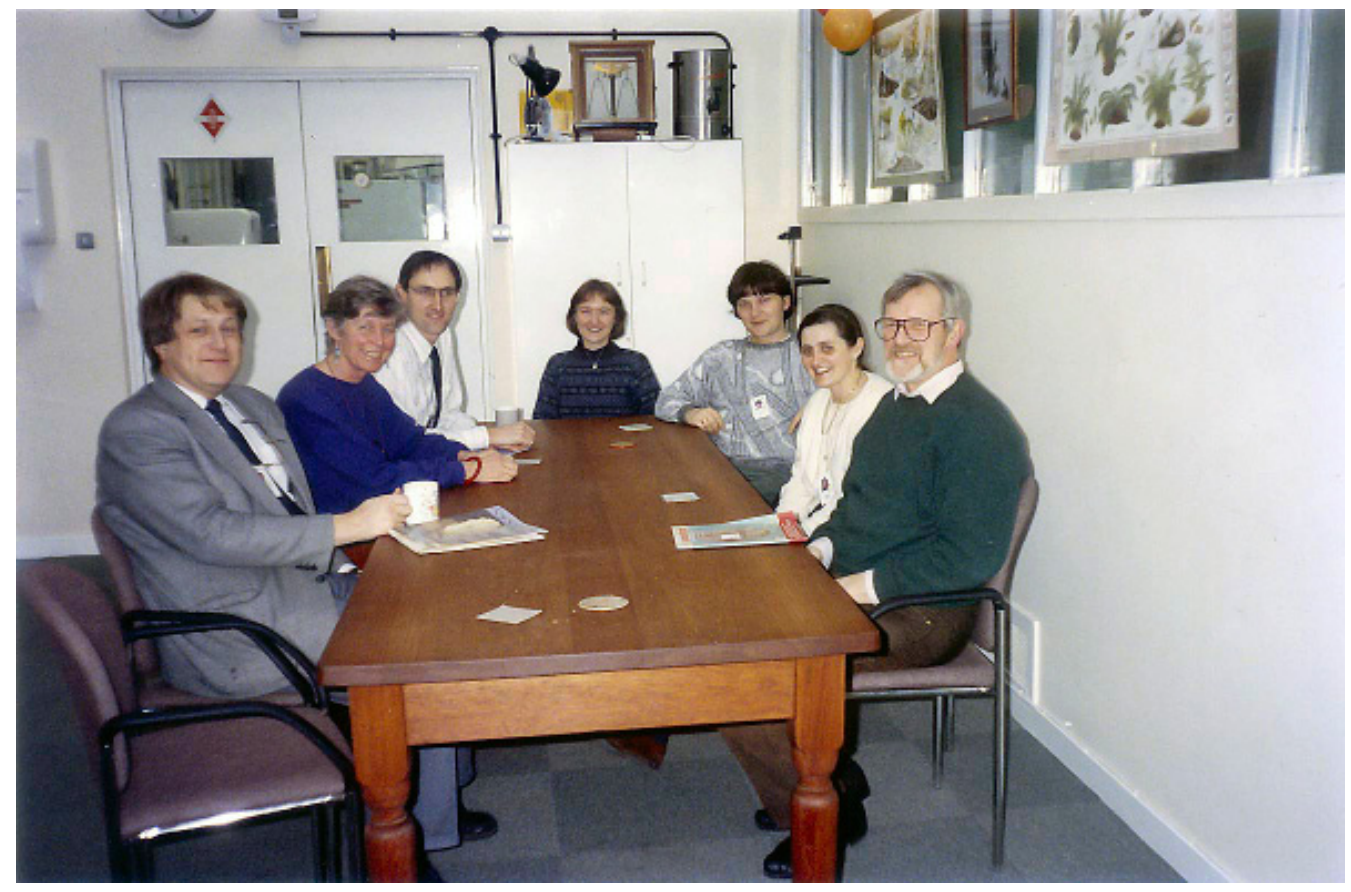

Fig. 4. "This image was taken back in 1992 - I believe - when we first met while working at the Natural History Museum London. The image was shared by William Purvis not long ago.” B. AguirreHudson. From left to right: Professor Per Magnus Jørgensen, Pat(ricia) A. Wolseley, William O. Purvis, Edit Farkas, László Lőkös, Begoña Aguirre-Hudson, and Peter James. (The photo was taken by Edna Smith, but 2 people are missing from the group: David Galloway, who was head of the lichen section/team at the time, and the lichen curator Robert Huxley). 
pioneer work, have done and organised mapping of the lichen flora of Hungary, discovered many new lichen-forming fungi for the country, used new chemical methods to identify lichen compounds, and have also involved and taught many young students and scientists to collaborate.

The couple contributed with 17 genera and 139 taxa, new for science and more than 120 new nomenclature combinations are proposed. 15 new taxa were named after them including two genera (Loekosiana and Loekoeslaszloa) named after László.

Fifty lichen species have been reported as new to Hungary and they are still working on new checklists and cryptic species to publish. Together they approach 400 publications distributed on scientific papers, conference abstracts and presentations.

Their extraordinary endurance and precision set a good example for their students.

\section{EDIT FARKAS}

Edit Éva Farkas was born on 1st of May, 1959 in Budapest, and grew up in the capital city of Hungary. Her father was an artist and taught engravers and gold- and silversmiths in a secondary school. Edit inherited his talent and later she made use of it in her publications (e.g. prepared own drawings of new taxa). In her early life, her grandparents living in the countryside had early a decisive on her. She spent her summer holidays in a small village, Nagyszakácsi in Somogy County. Her interest in biology was triggered by her biology teachers in elementary and secondary grammar school, however, she was also influenced by her elder brother who became a veterinary doctor.

As a pupil she wanted to know more about science and looked for an opportunity to work in a laboratory. She found a former Chinoin laboratory close to the street where she lived at that time, and spent a few weeks in a laboratory in the following summer as well. Thus, she became familiar with the laboratory work like chromatographic methods early.

After leaving the secondary grammar school in 1977, she started higher education at the Faculty of Science of the Eötvös Loránd University in Budapest, where she graduated as a biologist in 1982. In her diploma thesis, she dealt with the air quality indication by lichens in Budapest (FARKAS 1982), supervised by Klára Verseghy.

During the university years she aimed to learn more about biological systems mainly in supraindividual biology. She was interested in botany very much, so she spent most of her time at the Department of Plant Taxonomy and Ecology, 
where she was suggested by Edit Láng try to learn more about lichens from Klára Verseghy at the Botanical Department of the Hungarian Natural History Museum. By that time they had already known each other with László Lőkös, they had the same interest, so they started to work and study lichens together.

After her graduation as a biologist, between 1982-1984, she was employed as a research fellow at the Hungarian Academy of Sciences, Institute of Botany in Vácrátót (current name is Institute of Ecology and Botany, Centre for Ecological Research) with the supervision of Prof. Tamás Pócs. Since that time she has been working there in different positions and as the curator of the lichen herbarium VBI. Nowadays she is a scientific advisor and the team leader of the lichenological group.

She started her scientific carrier investigating air pollution and mapping with lichens as bioindicators in Budapest (VERSEGHY \& FAR KAS 1984, FAR KAS et al. 1985, FARKAS \& PÁTKAI 1989) and performing various floristical works in Hungary (FARKAS \& LöKös 1994, 1999, FARKAS \& TUBA 2005), however, she has specially focused on foliicolous lichens living mostly in the tropics. Her scientific work was largely influenced by the Bohemian lichenologist, A. Vězda, whom she admired, and who was introduced to her by Tamás Pócs (a well-known Hungarian bryologist). Farkas first met with Vězda in 1983 and she started to study tropical foliicolous lichens with him in order to identify them from the collections of Attila Borhidi and Tamás Pócs.

Her respect and affection for Antonín Vězda resulted in a Festschrift in occasion of his 75 years anniversary (FARKAS et al. 1995).

Later she participated in two longer expeditions in Tanzania $(1986,1989)$ (Figs 5-6) and published her results in various scientific papers (FARKAS 1987, 2015, FARKas \& VĚzda 1987, 1993, Farkas \& Pócs 1997, VĚzda \& Farkas 1988). She received material from all tropical regions of the world (FARKAS 1995, FARKAS \& HAWKSWORTH 2004) and this lichen group is still her favourite one inside lichenology. Recently she worked together with her Polish colleague, Adam Flakus (Fig. 7) on tropical material and they described Calopadia erythrocephala (FARKAS et al. 2012a) with a new lichen substance 'fusarubin', Lyromma coronatum and L. multisetulatum (FLAKUS \& FARKAS 2013) foliicolous lichen species, and a lichenicolous fungus, Keratosphaera antoniana living on foliicolous lichens (FARKAS 2010).

In honour of her master, A. Vězda, she started a small exsiccata series: "Notes and schedae to Lichenes Delicati Exsiccati Editae in memoriam Antonín Vězda (1920-2008)" (FARKAS 2010, 2011, 2014a,b).

Although she has an international reputation for investigating foliicolous lichens, she has been continuously working on local floristical works as well, especially on the chemical diversity of lichens and their special secondary metabolites, but interested in ecophysiology, too. 
She earned the degree of Candidate of Science (equivalent to $\mathrm{PhD}$ ) in 1987 for her thesis entitled "Investigation of the lichen flora in Budapest and in the Pilis Biosphere Reservation - distribution and bioindication" (FAR KAS 1990).

In 1992 she received a postdoctoral fellowship of the Royal Society London, thus she spent one year working in the British Natural History Museum, London with D. Galloway, who had also a great influence on her.

In order to investigate secondary lichen compounds, Edit Farkas introduced the thin layer chromatographic methods in lichenology in Hungary after 1998 (FARKAS et al. 1999b), and has used mostly the standard HPTLC method (ARUP et al. 1993). She and her students and co-workers identified more than 90 secondary lichen substances from about 150 lichen species. Together with Katalin Molnár they published a review about the current knowledge of lichen secondary chemistry (MOLNÁR \& FARKAS 2010) and started to investigate molecular genetic approach of some lichen taxa occurring in the country (MOLNÁR \& FARKAS 2011, MOLNÁR et al. 2012).

Edit is a member of numerous international scientific associations, such as the International Association for Lichenology (council member and treasurer 1996-2000), the British Lichen Society, the Bryologisch-lichenologische Arbeitsgemeinshaft für Mitteleuropa and the Nordic Lichen Society.

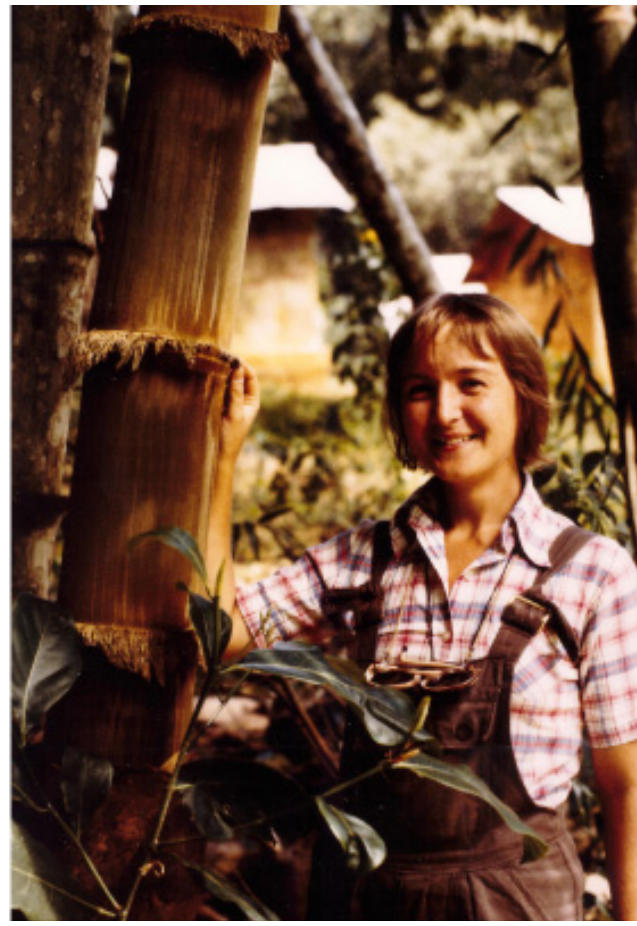

Fig. 5. Edit Farkas in Tanzania in 1986.

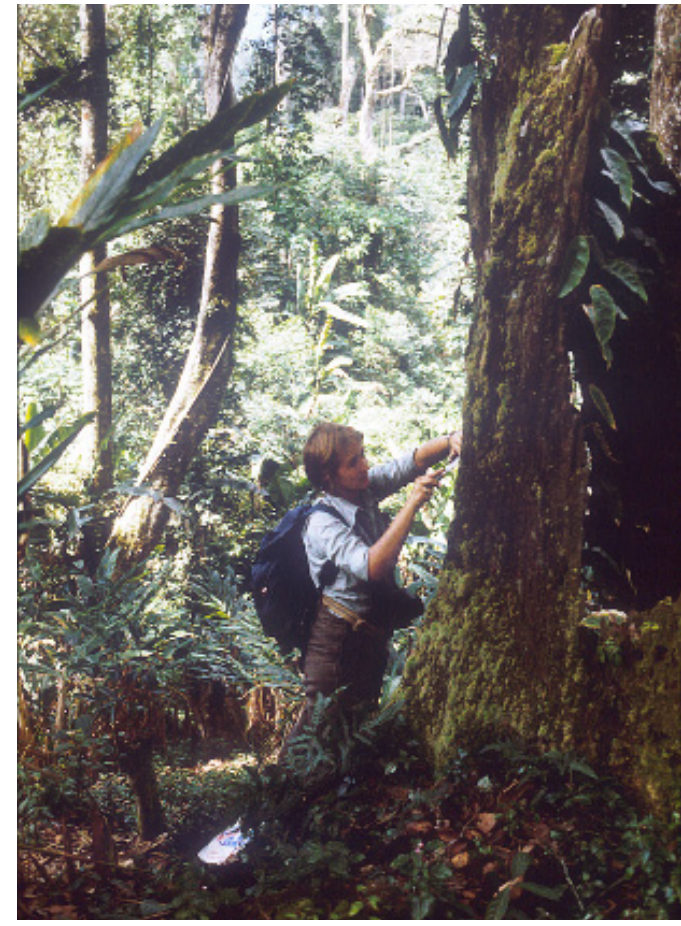

Fig. 6. Edit Farkas is collecting lichen samples in a rainforest, Tanzania, 1986. 


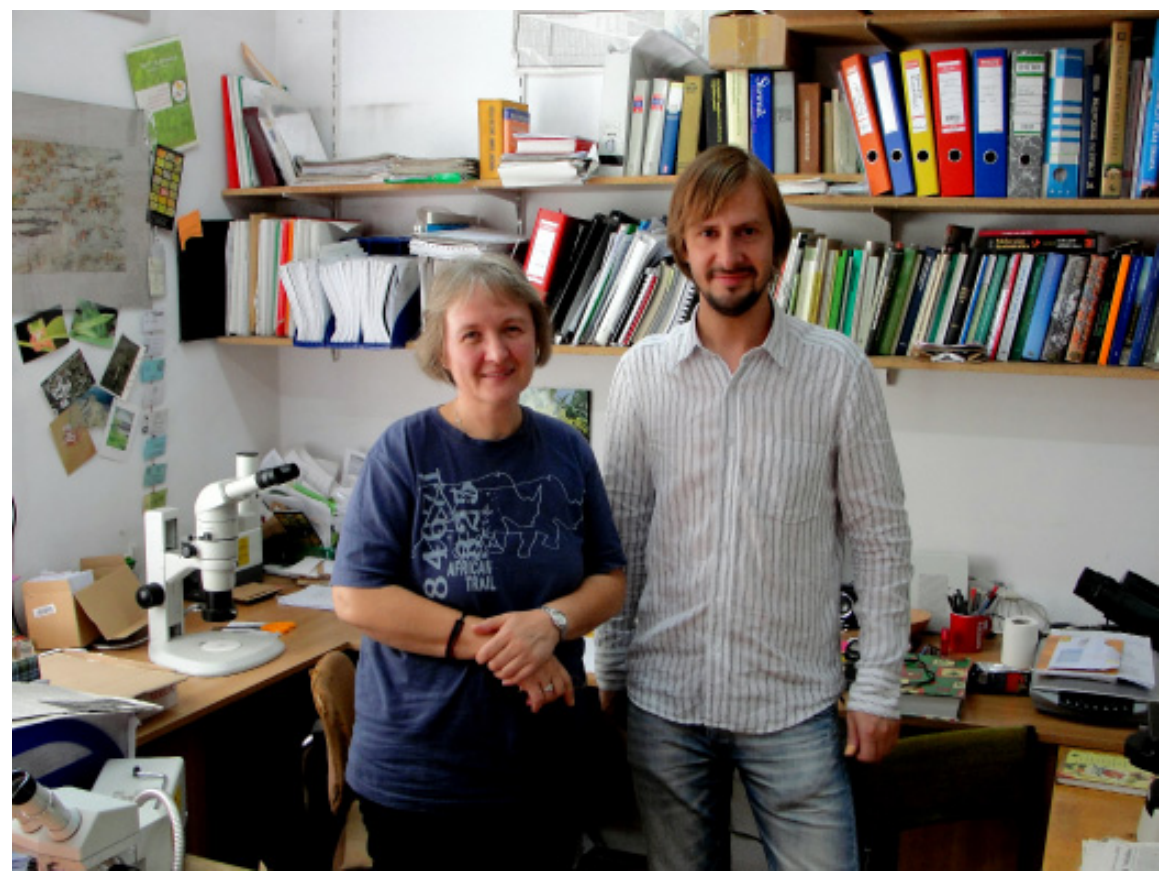

Fig. 7. Edit Farkas with her Polish colleague, Adam Flakus in Kraków, 2010. At that time they started to work on their foliicolous lichen collections from South America and Tanzania.

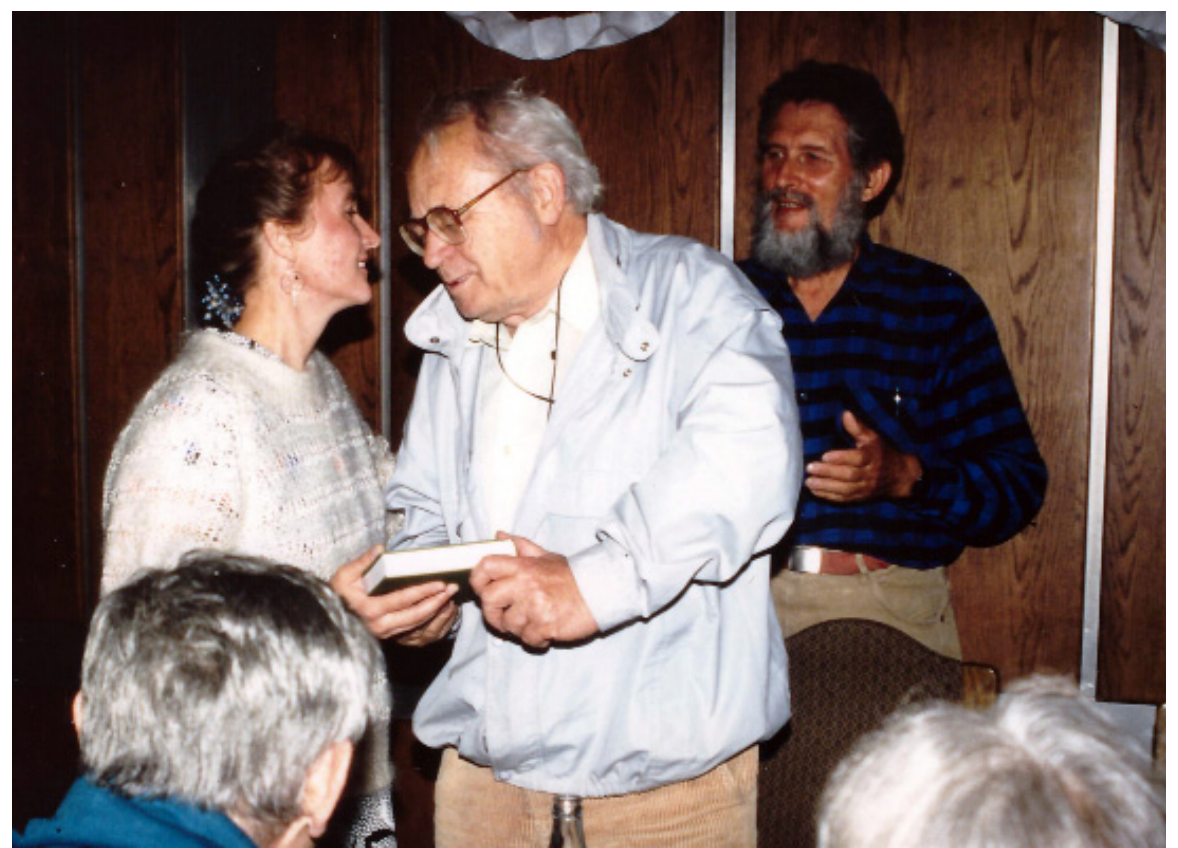

Fig. 8. Edit Farkas gives the Scripta Lichenologica over to Antonín Vězda. The photo was taken in 1995 on the IAB \& IAL Symposium on Foliicolous Cryptogams in Eger. Tamás Pócs is in the background. 
Beside her international role, she is an active member of many Hungarian and academic organizations and committees (Hungarian Biological Society, Hungarian Mycological Society, Hungarian Academy of Sciences Committee on Botany, Review Panels of OTKA, NKFI).

Since 1991, her investigations have been continuously supported by the Hungarian National Scientific Research Found (OTKA, NKFI). She organised numerous scientific meetings (IAB \& IAL Symposium on Foliicolous Cryptogams, Eger, Hungary 1995, Fig. 8; Young lichenologists' workshop in Hungary, 2009, 2015). She holds a special seminar in lichenology at the Eötvös Loránd University and Szent István University, and she is a member of a doctoral school of Biological Sciences of the Szent István University in Gödöllö.

She is an editorial and advisory member of three international journals (Biologia, 2017-, Kragujevac Journal of Science, 2018-, Thaiszia - Journal of Botany, 2019-).

She published the first book of lichenology in Hungarian with the title of "Lichenológia - a zuzmók tudománya", which is a synthetic work of the current knowledge of lichens including the history of lichen investigation, morphology, taxonomy, physiology, chemistry, distribution, and the usage of this group of fungi (FARKAS 2007).

Edit Farkas habilitated in 2012 and gain academic doctorate in 2016 (FARKAS 2016).

She is well known among colleagues and students as a warm-hearted person, very keen on the success and future of others.

\section{LÁSZLÓ LŐKÖS}

László Sándor Lőkös was born on 18th of June, 1959 in Siófok, Hungary, as the third son of his parents. He grew up in the countryside near Lake Balaton, thus he spent most of his time in the field, observing the animals, plants, and fungi as well as changes of the seasons in nature. This experience was determining for his further field of interest.

After leaving secondary grammar school in Veszprém, he attended the Faculty of Science of the Eötvös Loránd University in Budapest (after having spent one year in compulsory military service), where he graduated as a biologist in 1983. The topic of his MSc thesis was "Atomic absorption analysis of heavy metal contents of lichens transplanted in Budapest" (Lö Kös 1983) supervised by Klára Verseghy (Department of Botany, Hungarian Natural History Museum). Since the early years of the university he has been interested in systematics, but 
he was fond of the other subjects, such as anatomy, biomathematics, ecology, microbiology, mycology and physiology of various organisms as well.

After his graduation at the university he was working for two years at the Botanical Department of the University of Veterinary Science, Budapest. From 1985 up to the present he has been working for the Department of Botany, Hungarian Natural History Museum, Budapest, as the curator of the lichen herbarium. He followed Klára Verseghy in this position, who retired.

As a curator of the museum he joined the research on the flora, fauna, and cryptogams of the Hungarian national parks, such as the Kiskunság National Park (Lö Kös \& Verseghy 2001), Bükk National Park, and Aggtelek National Park (LöKös 2009), and published most of his findings. Exploration of the fauna and flora of the Hungarian protected areas (esp. national parks) was the main profile of the Hungarian Natural History Museum at that time.

Later, he carried out floristical research in several other parts of Hungary, such as Bakony Mts, Buda Mts, Kőszeg Mts, Mecsek Mts, Mt Naszály, Nyírség, Örség, Sopron Mts, Szigetköz, Tarna-vidék, Uppony Mts, Vendvidék, Villány Mts, Zemplén Mts, etc. (Csontos \& LöKös 1992, Csontos et al. 1996, 2000, 2007, FARKAS et al. 2000, 2013, 2014, 2016, KovÁcs \& Lö Kös 2016, Lö Kös 1989, 2000, 2010a, b, LöкÖs \& FARKAS 1998, 2000, LöKös et al. 1997, MolnáR \& LöKös 2007, Sinigla et al. 2017, SOMLYAY \& LöKös 1997, VARGA et al. 2016).

Besides his floristical works, he also performed taxonomic revisions. His main field of interest was the Bacidia s. l. group, which he started to investigate in 1994. He completed his PhD studies in 2005 in this topic at the University of Pécs (supervised by E. Farkas). The title of his thesis was "Taxonomic revision on the Hungarian Bacidia s. l. taxa” [original title: "A Bacidia s. l. zuzmónemzetség hazai fajainak taxonómiai revíziója"] (LőKös 2005), and his results were published in several scientific papers (FARKAs et al. 1998). Further taxonomic revisions on the Hungarian lichens carried out in various projects included the genera Arthopyrenia, Calicium, Chaenotheca, Cladonia p. p., Lepraria, Leptorhaphis, Solenospora, Umbilicaria, Toninia, Trapeliopsis, Xanthoparmelia, etc. (AgUIRREHudson et al. 2002, 2005, FAČKovCOvá et al. 2019, FARKAS et al. 1999b, 2011).

Gradually he got more and more opportunities to participate in collecting trips outside Hungary, as well as to work in international projects. The three main directions were 1. Romania (mostly the Transylvanian mountains), 2. the Balkan Peninsula, 3. and the Korean Peninsula.

Since the early 2000s, László has carried out research on the flora of several Transylvanian mountains in cooperation with Katalin Bartók. He published articles on the Pareng, Ruscă and Trascău Mts (BARTóк \& Lö Kös 2005, 2008, BARTÓK et al. 2006), then from 2009 he participated in four collecting trips in the Călimani (Kelemen) Mts as well (LöKös et al. 2018). 
He has frequently contributed to the cryptogam flora of the Balkan mainly with the bryologist of the museum, Beáta Papp, and later Peter Erzberger. In the first period, they organised expeditions mainly to Greece (1997, 2001, 2002, 2010, 2015; with E. Chatzinikolaki, M. Damanakis, E. Tsakiri, S. Pirintsos), then Serbia became the major direction of research (2000, 2002, 2003, 2004, 2005, 2006, 2010, 2012, 2013, 2016, 2018, 2019; with D. Dimović, M. Sabovljević) (Fig. 9), where the cryptogam flora of the national parks and protected areas was studied. Later, research was done in Bosnia-Herzegovina (2003), Slovenia (2003), Montenegro (2004, 2006, 2007, 2008; with S. Dragićević, B. Knezević), Bulgaria (2006, 2007, 2009, 2019; with A. Ganeva, R. Natcheva, S. Nikolova, V. Shivarov) (Figs 10-11), Macedonia (2010, 2013, 2016, 2018), and Croatia (2011) as well. László Lőkös joined the research on the flora of Albania in 2009, which was restarted by the botanists of the Hungarian Natural History Museum dealing with spermatophytes in 2004 (BARINA \& PIFKó 2019). Lőkös collected lichens in Albania several times (2009, 2010, 2011, 2012, 2015, 2016, 2017). He has published his findings in the above mentioned Balkan projects in numerous scientific papers (PAPP et al. 1999, LisickÁ et al. 2008, FARKAS et al. 2012b, SHIVAROV \& LöKös 2015, BURGAZ et al. 2019), and further results are expected.

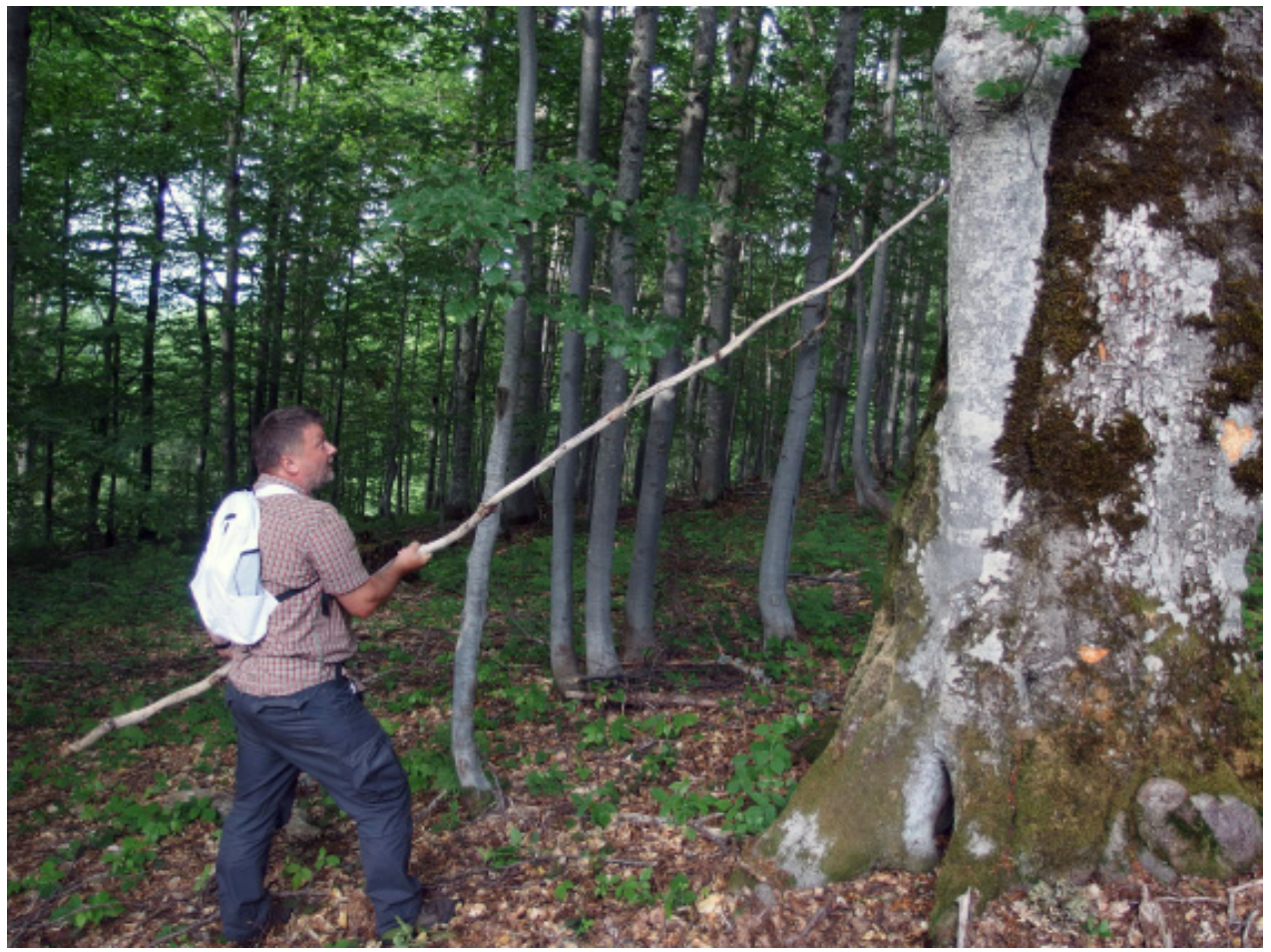

Fig. 9. Fieldwork in conference clothes, László Lőkös collecting lichen samples infected by lichenicolous fungi in a beech forest near the Peak Babin Zub, Serbia, June 2019 (photo: N. Varga). 


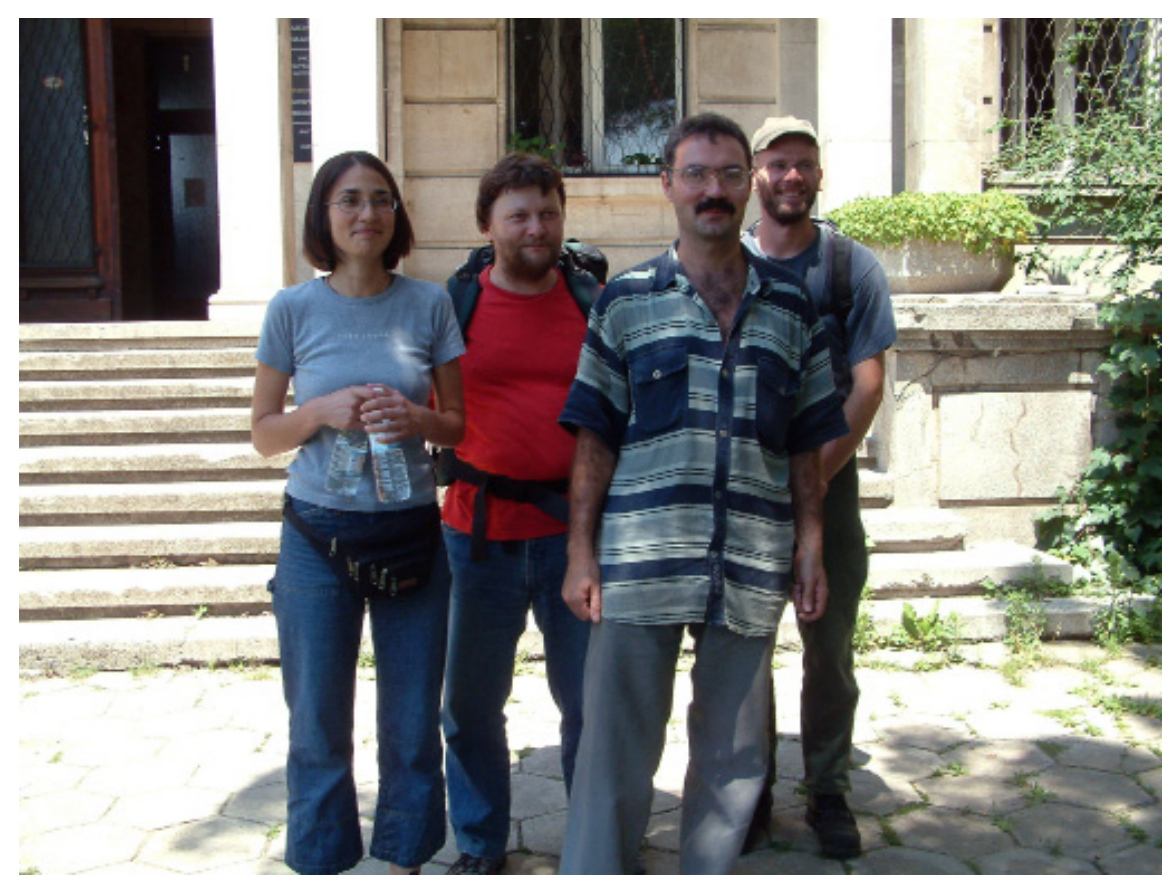

Fig. 10. Olga Siyka Nikolova, László Lőkös, Dimitar Stoykov, and Zoltán Barina in front of the building of the Bulgarian Academy of Sciences, Department of Botany, Sofia, Bulgaria, 2006.

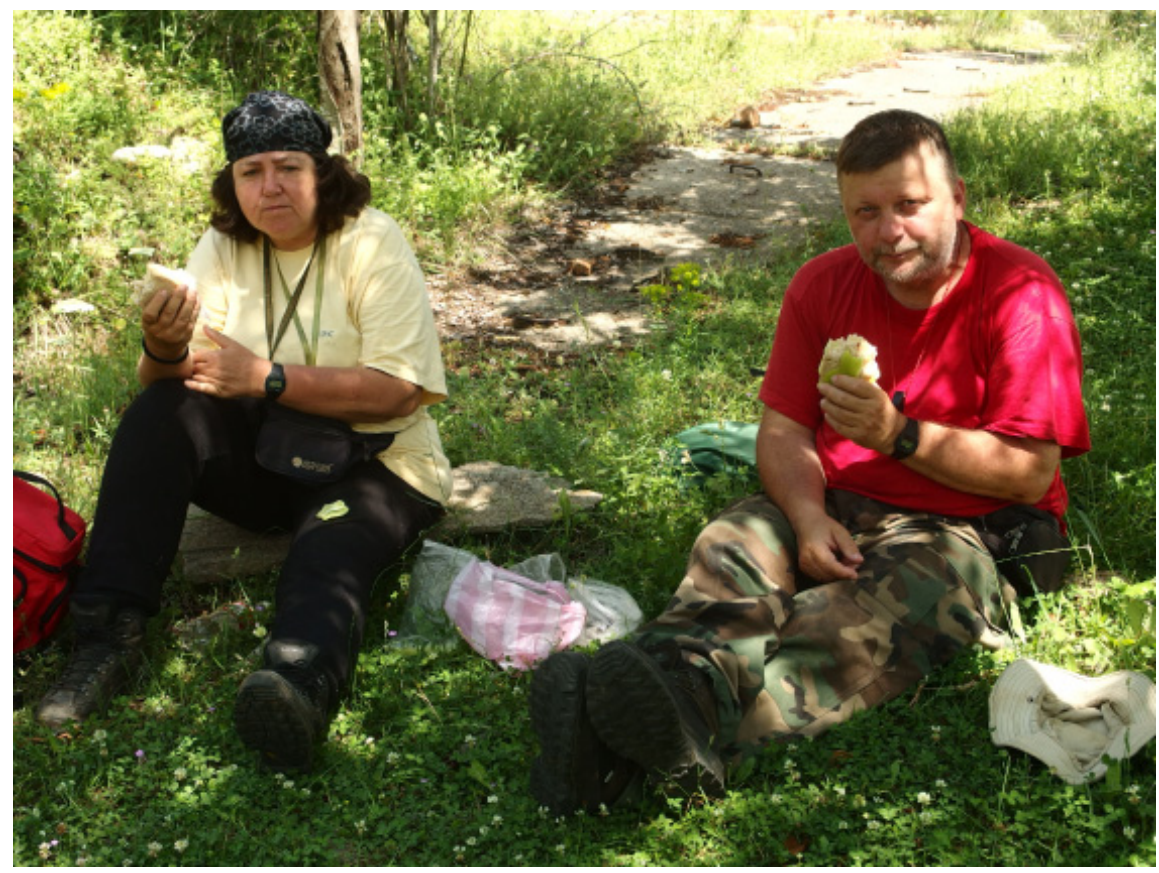

Fig. 11. At the southern foot of the Rila Mts investigating metal rich habitats of cryptogams. Lunch break with Beáta Papp, June 2019 (photo: N. Varga). 
The Korean Peninsula was also an important field of his research, when botanists of the Hungarian Natural History Museum had the opportunity to do research on the flora of North Korea in 1988 and 1994 (SZERDAHELYI \& Lö Kös 1992, Szollát \& LöKös 1994). Partly due to this experience, they managed to get in touch also with the South Korean colleagues in the 2000s. László Lőkös was invited by Prof. Jae-Seoun Hur, the director of the Korean Lichen Research Institute and the Department of Environmental Education of Sunchon National University to visit South Korea in 2005, 2007 and every year between 2012 and 2018, where he joined the research on the Korean lichen flora with his local colleagues, with the Czech lichenologist, Josef Halda and the Ukrainian lichenologist, Sergij Kondratyuk (Figs 12-13). They described numerous new lichenforming and lichenicolous fungi species in Korea together (JEON et al. 2009a, b, Joshi et al. 2010a, b, 2011a, b, 2013a, b, 2015, KONDRATYUK et al. 2012, 2013a, $b, c, 2014 a, b, c, 2015,2016 a-g, 2017,2018,2019$, MoNiRI et al. 2017) and published two volumes on the lichen flora of Korea (HUR et al. 2016, 2018), and a field guide of Ulleungdo and Dokdo lichens ( $\mathrm{OH}$ et al. 2019).

Besides the most important fields of research abroad, László Lőkös participated in several study trips, where he collected precious material for the lichen collection of the Hungarian Natural History Museum. These trips were organised together with his lepidopterist colleagues, László Peregovits and László Ronkay. He visited Nepal (1995), New Mexico (1996), Mongolia (1997) (Fig. 14), and participated in two study trips in China $(1996,2006)$ as well.

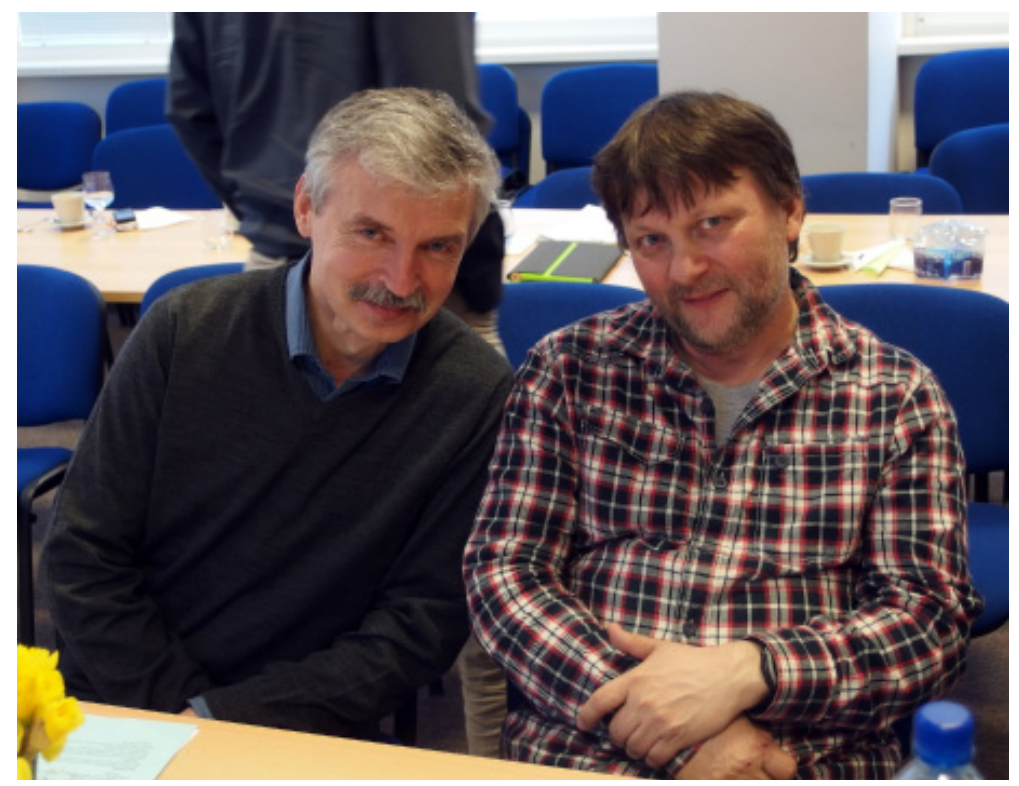

Fig. 12. Sergij Y. Kondratyuk and László Lőkös on a seminar taken to celebrate Ivan Pišút's 80th birthday in Bratislava, 2015 (photo: N. Varga). 


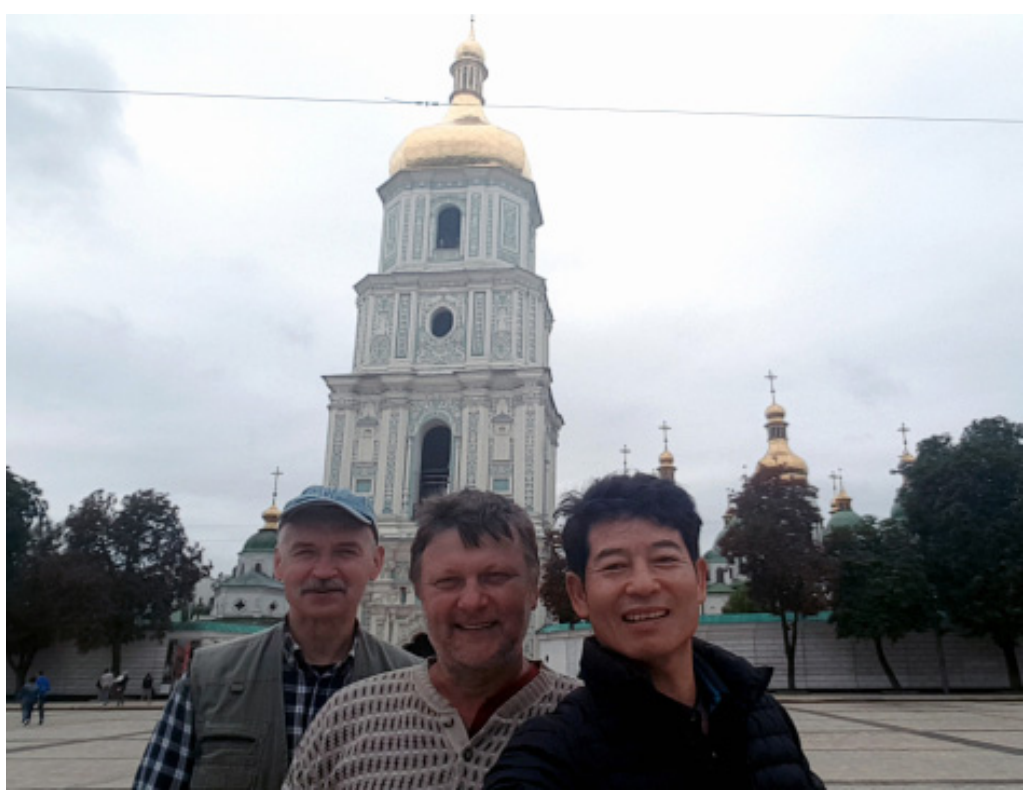

Fig. 13. Sergij Y. Kondratyuk, László Lőkös and Jae-Seoun Hur near St Sophia’s Cathedral in Kyiv, Ukraine, 2019 (photo: J.-S. Hur).

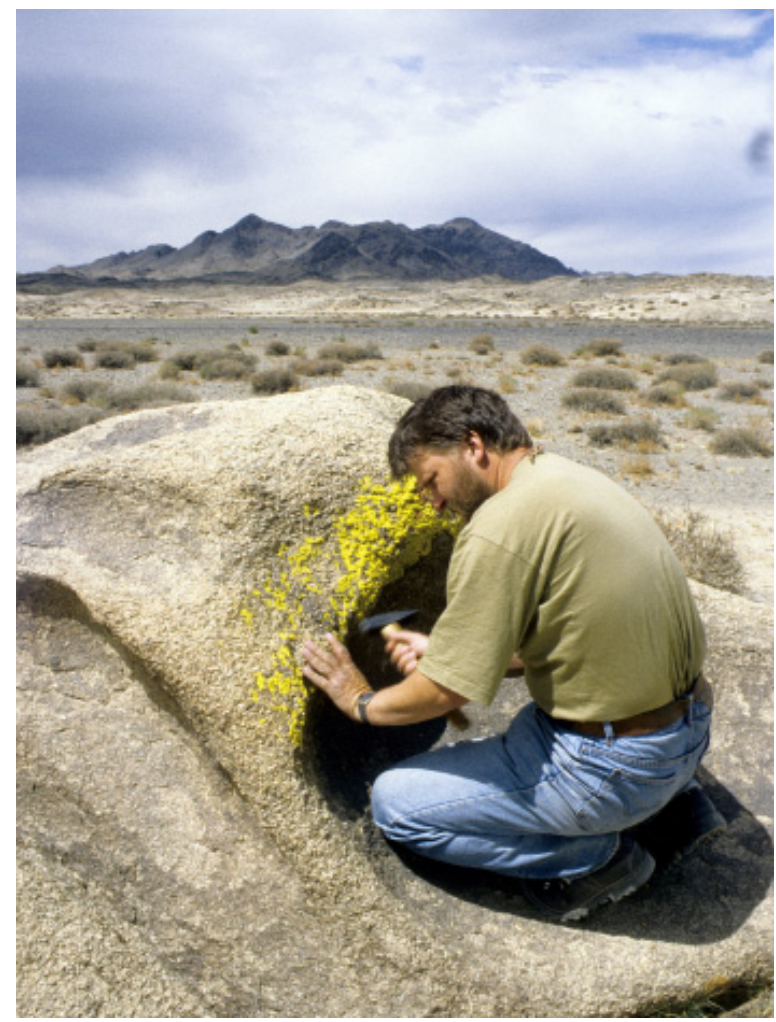

Fig. 14. László Lőkös collecting lichen samples in Mongolia in 1997 (photo: L. Peregovits). 
During his work as curator, he established professional contact with numerous foreign colleagues who visited the collection of the Natural History Museum, and they published their findings together. He published several scientific papers with his Turkish colleague, Ayhan Şenkardeşler (SENKARDESLER \& Lö KöS 2010, ŞENKARDEŞLER et al. 2011, 2014,2016), based on a joint collection trip in Turkey as well. Together with Jan Vondrák, he published studies on the lichens of the Bükk Mts (VoNDRÁK et al. 2009), as well as a number of new lichen taxa are described from Ukraine (KONDRATYUK et al. 2014, 2015b, 2019).

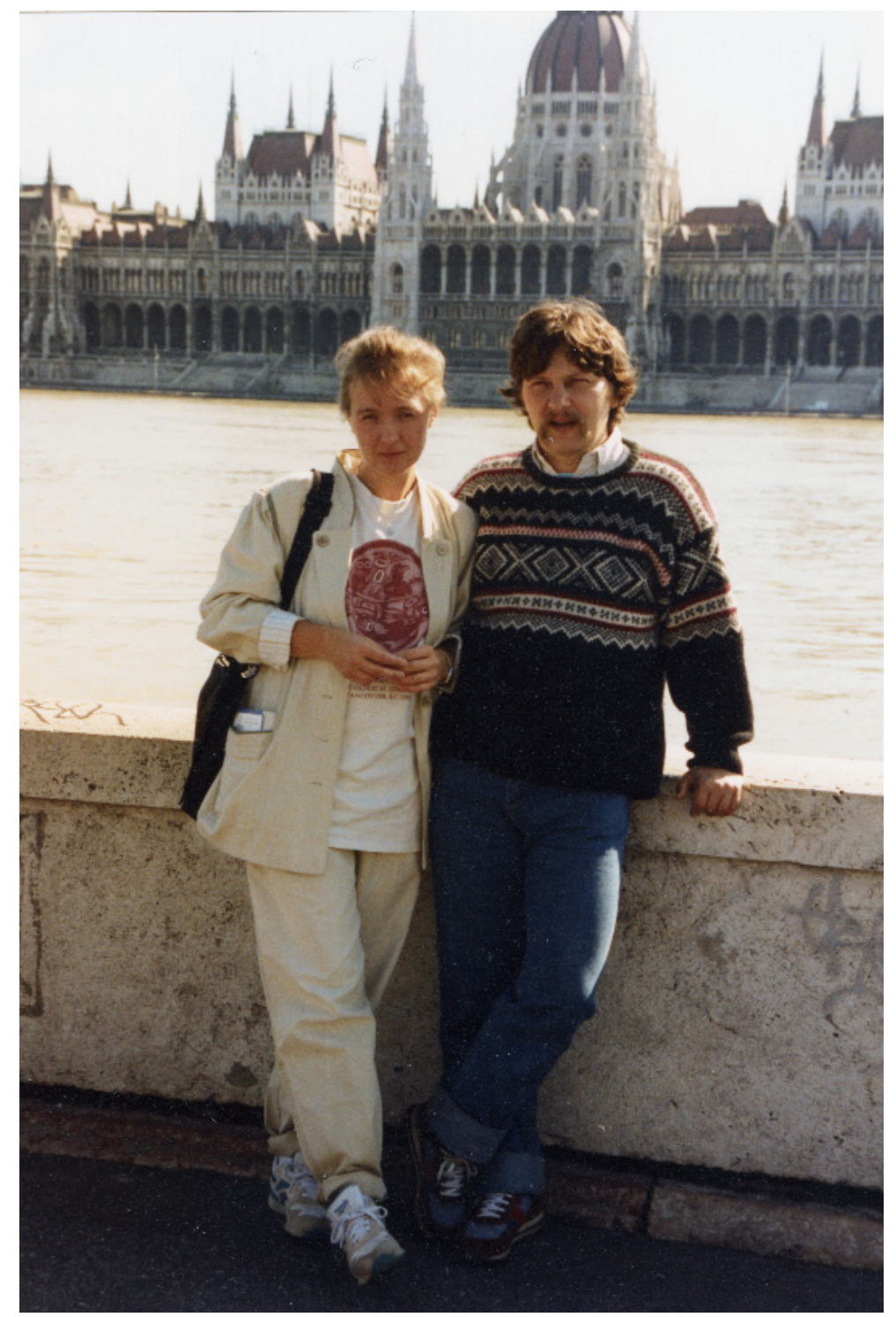

Fig. 15. Edit Farkas and László Lőkös in Budapest in 1995 (photo: I. Kärnefelt). 
Recently, he has worked together with several Hungarian colleagues and students on different topics: e.g. with Gábor Matus on the lichen flora of Debrecen and the Nyírség (MATus et al. 2017); with Dániel Kovács on the lichen flora of the Mecsek Mts (KovÁcs \& LöKös 2016); with Lajos Balogh on the historical lichen collections of V. Piers and A. Waisbecker (BALOGH et al. 2004, LöKös \& BALOGH 2016); with Zoltán Varga on the lichens from Vésztő and surroundings; with Csaba Németh on the lichens from Bakony, Keszthely and Vértes Mts and on his Solorina saccata collections (SINIGLA et al. 2018); with József Nagy on the lichens of the Börzsöny Mts; as well as with Mónika Sinigla on the lichen flora of the Bakony Mts and on the Hungarian distribution of protected lichen species (Sinigla et al. 2014, 2015, 2017, 2018).

$\mathrm{He}$ is also interested in lichenicolous fungi, thus he has had several publications in cooperation with Nóra Varga and Sergij Y. Kondratyuk (e.g. Joshi et al. 2015, KondRATYUK et al. 2016f, 2018, LöKÖs et al. 2018, VARGA et al. 2016).

Besides his scientific work, he has considerable editorial activities in Hungarian botanical journals. He has been the technical editor of the journal Studia Botanica Hungarica since 1988 and the editor of Vols 24-28 (SZURDOKI 2019); the managing editor of Acta Botanica Hungarica since 1998; and the co-editor of the journal Clusiana (Mikológiai Közlemények) since 2004. In addition, he participated in the technical editing process of more than 30 scientific books.

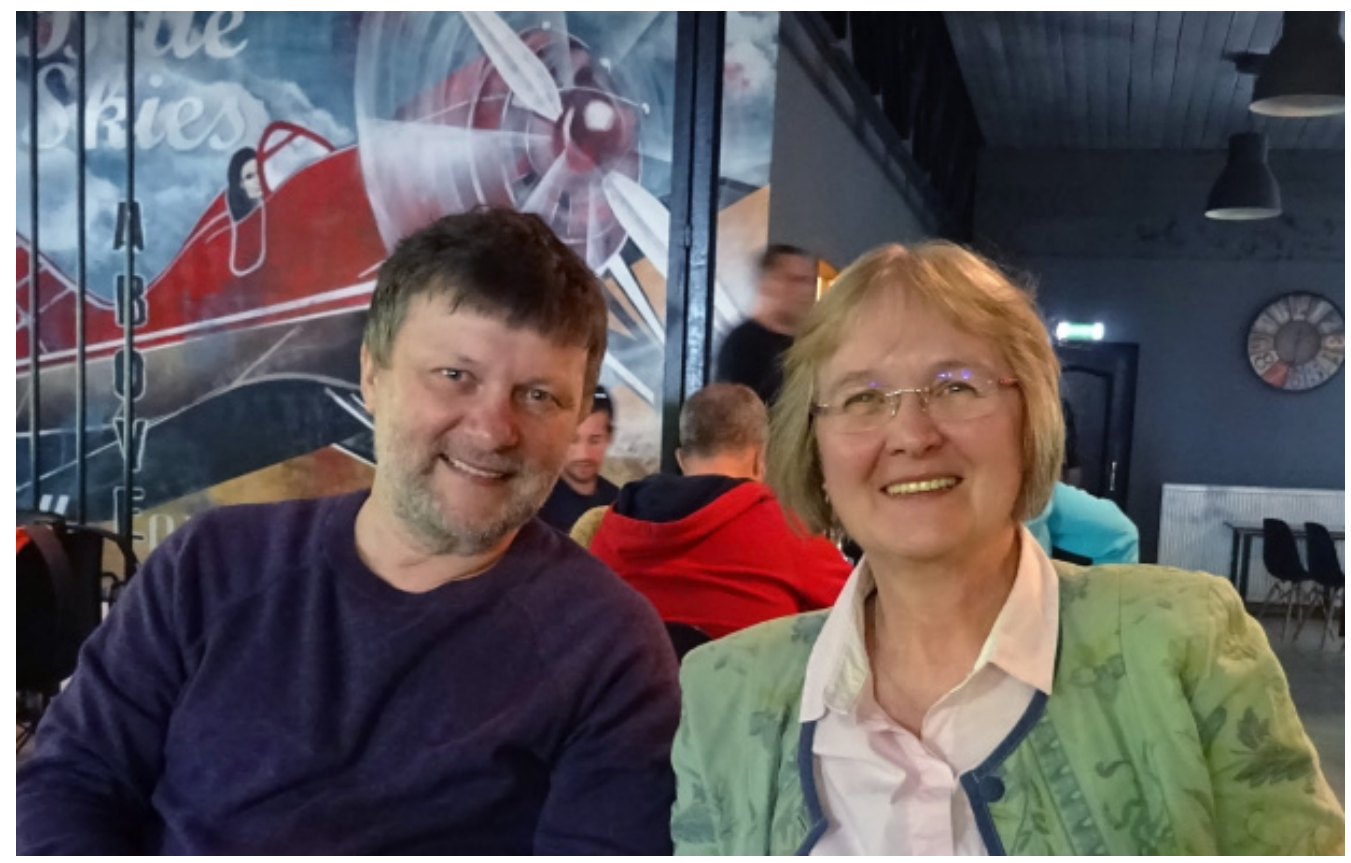

Fig. 16. Edit Farkas and László Lőkös in Budapest in 2019 (photo: Laura Lőkös). 
He had been the 'notary' of the Section of Botany of the Hungarian Biological Society for a long time (1998-2014), and at that time he was the columnist of 'Növénytani Szakülések'.

László is a great friend and colleague with a special sense of humour that makes life easier (especially) in the field.

We wish them both all the best in the future with joint meetings, field trips and new discoveries.

Összefoglaló: Farkas Edit és Lőkös László a magyar lichenológiai kutatás nemzetközileg ismert és elismert alakjai. Sokat tettek azért, hogy ez a tudományterület megmaradjon, fejlődjön és világszinten is ismert legyen. A hazai zuzmóflóra mellett gyűjtéseikkel gazdagították a magyar gyűjteményeket trópusi és főleg balkáni anyagokkal. Munkásságuk a florisztikai kutatások mellett kiterjed a morfológiai, kémiai és molekuláris biológiai alapú taxonómiai revíziókra, tudományra új zuzmók leírására, ökofiziológiai kutatásokra, valamint a zuzmólakó gombák vizsgálatára is. Ezek mellett tudománytörténeti kutatásaik is jelentősek. Mivel idén töltötték be 60 . életévüket, ez alkalomból köszöntjük őket, $s$ cikkünkben röviden megemlékezünk eddigi munkásságukról, amit több mint száz tudományos cikk, hasonló számú tudományos és ismeretterjesztő előadás fémjelez. Kitartó és precíz munkájuk példaként áll tanítványaik és kollégáik előtt.

\section{REFERENCES}

Aguirre-Hudson B., Farkas E. \& LöKös L. (2002): Pyrenolichens of the Hungarian lichen flora I: The genus Leptorhaphis Körber. - Bibl. Lichenol. 82: 3-18.

Aguirre-Hudson B., Farkas E. \& LöKös L. (2005): New records of Leptorhaphis and other ascomycete genera from the Carpathian basin (Europe). - Herzogia 18: 47-50.

ARup U., Ekman S., Lindblom L. \& MatTsson J.-E. (1993): High performance thin layer chromatography (HPTLC), an improved technique for screening lichen substances. - Lichenologist 25(1): 61-71. https://doi.org/10.1017/s0024282993000076

BALOGH L., LÖKÖs L., PAPP B. \& VASAS G. (2004): Herbarium Waisbeckerianum. 1. Waisbecker Antal herbáriumának Piers Vilmos által összeállított gomba-, zuzmó- és mohagyűjteménye a szombathelyi Savaria Múzeumban. - Savaria, a Vas megyei Múzeumok Értesitóje 28: 7-47.

BARINA Z. \& Pif Kó D. (2018): Növénytani kutatásaink Albániában. - Annls Mus. hist.-nat. hung. 110: 77-93.

BARTók K. \& LöKös L. (2005): Contributions to the lichen flora and lichen ecology in the Parâng and Lotru Mountains (Southern Carpathians). - Contrib. Bot. 39: 41-49.

BARTóк K. \& Löкös L. (2008): Contributions to the lichen flora of Trascău Mountains (Alba County, Romania). - Contrib. Bot. 42: 27-34.

BARTó к K., Guttová A. \& Lö Kös L. (2006): Contributions to the epiphytic lichen flora of Poiana Ruscă Mts, Southern Carpathians (SW Romania). - Contrib. Bot. 40: 59-64. (2005).

Burgaz A. R., Luna-González S., Gutiérrez-Larruga B., Pino-Bodas R., Lökös L. \& FARKAS E. (2019): Diversity of Albanian Cladoniaceae. - Bot. Complutensis 43: 15-40. https://doi.org/10.5209/BOCM.63970

Csontos P. \& Löкös L. (1992): Védett edényes fajok térbeli eloszlás-vizsgálata a Budai hg. dolomitvidékén - szünbotanikai alapozás természetvédelmi területek felméréséhez. (The analysis 
of the spatial distribution of protected vascular plant species on a dolomite region of Budaimts., Hungary - synbotanical approach to the evaluation of nature reserves.) - Bot. Közlem. 79(2): 121-143.

Csontos P., Lökös L. \& Molnár K. (2000): Numerical analysis of lichen zones in Komárom, NW Hungary. - Studia bot. hung. 30-31: 127-140.

Csontos P., Horánszky A., KAlapos T. \& Lökös, L. (1996): Seed bank of Pinus nigra plantations in dolomite rock grassland habitats, and its implications for restoration of the grassland vegetation. - Annls hist.-nat. Mus. natn. Hung. 88: 69-77.

Csontos P., IsÉPy I., TAMÁs J. \& LöKös L. (2007): Védett növényfajok együttes előfordulása szárazgyepekben. (Co-existence of protected plant species in dry grasslands). - Tájökol. Lapok 5(2): 249-260.

FaČkovcová Z., Lökös L., FARKas E. \& Guttová A. (2019): New records of the lichen genus Solenopsora A. Massal in the Balkan Peninsula and adjacent islands. - Herzogia 32(1): 101-110.

FARKAS E. (1982): Légszennyezödési vizsgálatok Budapest területén zuzmó-bioindikátorokkal. - Manuscript, MSc Thesis, ELTE TTK, Növényrendszertani és Ökológiai Tanszék, Budapest, 91 pp.

FARKAS E. (1987): Foliicolous lichens of the Usambara Mountains, Tanzania I. - Lichenologist 19: 43-59. https://doi.org/10.1017/s0024282987000057

FARKAS E. (1990): Lichenológiai vizsgálatok Budapesten és a Pilis Bioszféra Rezervátumban - elterjedés, bioindikáció. (Investigation of the lichen flora in Budapest and in the Pilis Biosphere Reservation - distribution and bioindication.) (In Hungarian.) - Manuscript, PhD Thesis, MTA ÖBKI, Vácrátót, $121 \mathrm{pp}$.

FARKAS E. (1995): Notes on the genus Sarrameana Vězda et P. James and some blackfruited species of Bacidia s. 1. (Lichenized Ascomycetes). - Bibl. Lichenol. 58: 97-106.

FARKAS E. (2007): Lichenológia - a zuzmók tudománya. - MTA Ökológiai és Botanikai Kutatóintézete, Vácrátót, $193 \mathrm{pp}$.

FARKAS E. (2010): Notes and schedae to Lichenes Delicati Exsiccati Editae in memoriam Antonín Vězda (1920-2008), Fasc. 1. - Acta Bot. Hung. 52: 331-340. https://doi.org/10.1556/abot.52.2010.3-4.11

FARKAS E. (2011): Notes and schedae to Lichenes Delicati Exsiccati Editae in memoriam Antonín Vězda (1920-2008), Fasc. 2. - Acta Bot. Hung. 53: 101-109.

https://doi.org/10.1556/abot.53.2011.1-2.9

FARKAS E. (2014a): Notes and schedae to Lichenes Delicati Exsiccati Editae in memoriam Antonín Vězda (1920-2008). Fasc. 3. - Acta Bot. Hung. 56(1-2): 69-76. https://doi.org/10.1556/abot.56.2014.1-2.8

FARKAS E. (2014b): Notes and schedae to Lichenes Delicati Exsiccati Editae in memoriam Antonín Vězda (1920-2008). Fasc. 4. - Acta Bot. Hung. 56(3-4): 305-317. https://doi.org/10.1556/abot.56.2014.3-4.7

FARKAS E. (2015): Foliicolous lichen collections on Mount Kanga, Tanzania (East Africa). - Acta Bot. Hung. 57(1-2): 41-50. https://doi.org/10.1556/abot.57.2015.1-2.7

FARKAS E. (2016): A bioindikáció, a biodiverzitásés a kémiai diverzitás összefüggései a lichenológiában. - Academic Doctorate Thesis, MTA Ökológiai Kutatóközpont, pp. 112.

FARKas E. \& Hawksworth D. L. (2004): New foliicolous lichen records from two different habitats in Trinidad. - Caribbean J. Sci. 40(3): 399-401.

FARKAS E. \& LöKös L. (1994): Distribution of the lichens Cladonia magyarica Vain., and Solorinella asteriscus Anzi in Europe. - Acta Bot. Fennica 150: 21-30.

FARKAs E., \& LöKös L. (1999): The research of lichenized fungi in Hungary. - Acta Microbiol. Immunol. Hung. 46(2-3): 199-203. https://doi.org/10.1556/amicr.46.1999.2-3.7 
FARKAS E. \& LöKÖs L. (2003): Védelemre javasolt fajok. Zuzmók (lichenizált gombák). 2. javaslat. 23 zuzmófaj (10 fokozottan védett, 13 védett). - Budapest, mscr.

FARKAS E. \& LöKÖs L. (2004): Védelemre javasolt fajok. Zuzmók (lichenizált gombák). 3. javaslat. 5 védett zuzmófaj. - Budapest, mscr.

FARKAS E. \& LöKös L. (2007): Védett zuzmófajok Magyarországon. (Protected lichen species in Hungary). - Mikol. Közlem., Clusiana 45(1-3): 159-171.

FARKAS E. \& PÁTKAI T. (1989): Lichens as indicators of air pollution in the Budapest agglomeration. II. Energy dispersive X-ray microanalysis of Hypogymnia physodes (L.) Nyl. thalli. Acta Bot. Hung. 35(1-4): 55-71.

FARKas E. \& Pócs T. (eds) (1997): Cryptogams in the phyllosphere: systematics, distribution, ecology and use. - Abstracta Botanica 21(1): 1-216.

FARKAS E. \& Tuba Z. (2005): Contributions to the lichen flora of the Hungarian Bodrogköz (NE Hungary). - Thaiszia 15: 129-141.

FARKAS E. \& VĚZDA A. (1987): Macentina borhidii, eine neue foliicole Flechte aus Tansania. Acta Bot. Hung. 33(3-4): 295-300.

FARKas E. \& VĚZda A. (1993): Five new foliicolous lichen species. - Folia Geob. Phytotax. 28: 321-330. https://doi.org/10.1007/bf02853518

FARKas E., Elix J. A. \& Flakus A. (2012a): Calopadia erythrocephala, a new foliicolous lichenised fungus from Brazil. - Lichenologist 44(3): 395-399. https://doi.org/10.1017/s0024282911000831

FARKAS E., LöKös L. \& MÁzsA K. (1999b): Introducing HPTLC analysis for screening of lichen substances in Hungary. - Acta Microbiol. Immunol. Hung. 46: 311-312.

FARKAS E., LöKÖs L. \& MOLNÁR K. (2001): Lichen mapping in Komárom, NW Hungary. - Acta Bot. Hung. 43(1-4): 147-162. https://doi.org/10.1556/abot.43.2001.1-2.8

FARKAS E., LÖKÖs L. \& MolNÁR K. (2012b): Új adatok a Xanthoparmelia zuzmófajok elterjedéséhez a Balkán térségben. (New Xanthoparmelia (Parmeliaceae, lichenized Ascomycota) records from the Balkan region). - Clusiana 51(1): 71-72.

FARKAS E., LŐKÖs L. \& MoLNÁR K. (2013): Zuzmók biodiverzitás-vizsgálata a szentbékkállai „Fekete-hegy” mintaterületen. (Biodiversity of lichen-forming fungi on Fekete Hill (Szentbékkálla, Hungary)). - Folia Mus. Hist.-nat. Bakony. 29: 29-46. (2012).

FARKAS E., LöKös L. \& Tóth E. (1998): Bacidia species in Hungary. - Sauteria 9: 133-141.

FARKAS E., LöKös L. \& TóTH E. (1999a): Védelemre javasolt fajok. Zuzmók (lichenizált gombák). 108 zuzmófaj ( 29 fokozottan védett, 79 védett). - Budapest, mscr.

FARKAS E., LÖKÖS L. \& VERSEGHY K. (1985): Lichens as indicators of air pollution in the Budapest Agglomeration. I. Air pollution map based on floristic data and heavy metal concentration measurements. - Acta Bot. Hung. 31(1-4): 45-68.

FARKAS E., LÜCKING R. \& WIRTH V. (eds) (1995): Scripta Lichenologica - Lichenological papers dedicated to Antonín Vězda. - Bibl. Lichenol. 58: 1-501.

FArkas E., Guttová A., LöKös L. \& MolNÁr K. (2011): Distribution of Solenopsora candicans (lichen-forming fungi, Catillariaceae) in Hungary. - Acta Bot. Hung. 53(3-4): 305-311. https://doi.org/10.1556/abot.53.2011.3-4.12

FARKas E., Lőkös L., Sinigla M. \& VARGA N. (2014): A Mogyorós-hegy (Litér) és az Ugri-hegy (Királyszentistván) zuzmóflórája. (The lichen flora of the hills "Mogyorós-hegy" (Litér, Hungary) and "Ugri-hegy" (Királyszentistván, Hungary)). - Folia Mus. Hist.-nat. Bakony. 31: 7-24.

FARKas E., LöKös L., PAPP B., Sinigla M. \& VARGA N. (2016): Zuzmók és mohák biodiverzitásvizsgálata a szigligeti Kongó-rétek mintaterületen. (Biodiversity of bryophytes, lichen-form- 
ing and lichenicolous fungi on "Kongó Meadows" (Hegymagas-Szigliget, Hungary)). - Folia Mus. Hist.-nat. Bakony. 33: 19-33.

Flakus A. \& FARKAS E. (2013): A contribution to the taxonomy of Lyromma (Lyrommataceae, lichenized Ascomycota) with a species key. - Mycotaxon 124: 127-141. https://doi.org/10.5248/124.127

JeON H.-S., Кон Y. J., LöKös L., LeE Y. M., BYUN B.-K. \& HUR J.-S. (2009a): Report on the lichen list of North Korea. - Kor. J. Mycol. 37(1): 1-10. https://doi.org/10.4489/kjm.2009.37.1.001

Jeon H-S., Löкös L., Han K. S., RYu J.-A., Kim J. A., Кон Y. J. \& HuR J.-S. (2009b): Isolation of lichen-forming fungi from Hungarian lichens and their antifungal activity against fungal pathogens of hot pepper anthracnose. - Plant Pathol. J. 25(1): 38-46. https://doi.org/10.5423/ppj.2009.25.1.038

Joshi S., Jayalal U., Lökös L., Park J.-S., OH S.-O., Koh Y. J. \& HuR J.-S. (2013a): Leiorreuma exaltatum and Trapelia coarctata, new to Korean lichen flora. - Mycobiology 41(1): 56-58. https://doi.org/10.5941/myco.2013.41.1.56

Joshi S., Кон Y. J., Löкös L., JaYALAL U. \& HUR J.-S. (2013b): Graphis koreana (Graphidaceae, Ostropales), a new species from South Korea. - Lichenologist 45(5): 593-597. https://doi. org/10.1017/s0024282913000224

Joshi Y., Kondratyuk S., Lökös L., Halda. J. P., OH S.-O. \& HuR J.-S. (2015): New species and new records of lichenicolous fungi from South Korea. - Mycosphere 6(4): 493-500. https://doi.org/10.5943/mycosphere/6/4/11

Joshi Y., Lökös L., WANG X. Y., NGUYen T. T., Кон Y. J. \& HUR J.-S. (2010a): Identification of Sculptolumina japonica (Physciaceae) in South Korea. - Mycobiology 38(1): 62-64. https://doi: 10.4489/MYCO.2010.38.1.062.

Joshi Y., NguYen T. T., Lökös L., Кон Y. J. \& HuR J.-S. (2011a): Two new records of the lichen genus Placynthiella Elenkin in South Korea. - Mycobiology 39(1): 54-56.

Joshi Y., Nguyen T. T., Wang X. Y., Löкös L., Kон Y. J. \& HUR J.-S. (2011b): Contribution to the lichen mycota of South Korea. - Mycotaxon 1 16: 61-74. https://doi.org/10.5248/116.61

Joshi Y., WANG X. Y., Löкös L., Kон Y. J. \& HuR J.-S. (2010b): Notes on lichen genus Buellia De Not. (lichenized Ascomycetes) from South Korea. - Mycobiology 38(1): 65-69. https://doi.org/10.4489/myco.2010.38.1.065

HuR J.-S., OH S.-O. etc. (eds) (2016): Flora of macrolichens in Korea. - Korea National Arboretum, Pocheon, $520 \mathrm{pp}$.

Hur J.-S., Oh S.-O., Park J.-S., Lökös L., Kondratyuk S., Bae J. K. \& OH S. H. (2018): Flora of microlichens in Korea. - Korea National Arboretum, Pocheon, 486 pp.

Kondratyuk S. Y., Lökös L., Zarei-Darki B. \& HUR J.-S. (2012): New and rediscovered Caloplacas (Teloschistaceae, Ascomycota) from Asia. - Acta Bot. Hung. 54(3-4): 313-339. https://doi.org/10.1556/abot.54.2012.3-4.10

Kondratyuk S. Y., Lökös L., Zarei-Darki B., Haji Moniri M., Tchabanenko S. I., Galanina I., Yakovchenko L., Hooshmand F., Ezhkin A. K. \& Hur J.-S. (2013a): Five new Caloplaca species (Teloschistaceae, Ascomycota) from Asia. - Acta Bot. Hung. 55(1-2): 41-60. https://doi.org/10.12697/fce.2013.50.06

Kondratyuk S., Lökös L., Tschabanenko S., Haji Moniri M., Farkas E., Wang X. Y., Oh S.-O. \& HUR J.-S. (2013b): New and noteworthy lichen-forming and lichenicolous fungi. Acta Bot. Hung. 55(3-4): 275-349. https://doi.org/10.7320/flmedit27.175

Kondratyuk S., Yatsyna A. P., Lökös L., Galanina I., Haji Moniri M. \& Hur J.-S. (2013c): Three new Xanthoria and Rusavskia species (Teloschistaceae, Ascomycota) from Europe. Acta Bot. Hung. 55(3-4): 351-365. https://doi.org/10.1556/abot.55.2013.3-4.10 
KondRATYUK S. Y., LöKös L. \& HUR J.-S. (2014): New lichen-forming and lichenicolous fungi from Ukraine. - Acta Bot. Hung. 56(3-4): 359-366.

https://doi.org/10.1556/ABot.56.2014.3-4.11

Kondratyuk S. Y., Lökös L., Kim J. A., Kondratiuk A. S., Jeong M. H., Jang S. H., OH S.-O. \& HUR J.-S. (2015a): Three new monotypic genera of the caloplacoid lichens (Teloschistaceae, lichen-forming Ascomycetes). - Mycobiology 43(3): 195-202.

https://doi.org/10.5941/myco.2015.43.3.195

Kondratyuk S. Y., Lökös L., Kapetz N. V., Pleskach L. Ya., Kim J., Kondratiuk A. S. \& Hur J.-S. (2015b) Physcia ucrainica sp. nova (Physciaceae, Ascomycota) from the Crimean peninsula, proved by molecular phylogeny. - Acta Bot. Hung. 57(1-2): 143-163. https://doi.org/10.1556/ABot.57.2015.1-2.11

Kondratyuk S. Y., LöKös L., Kärnefelt I., Thell A., Elix J. A., OH S.-O. \& Hur J.-S. (2016a): Three new Orientophila species (Teloschistaceae, Ascomycota) from Eastern Asia. - Graphis Scripta 28(1-2): 50-58.

Kondratyuk S. Y., Lökös L., Halda J. P., Lee B. G., Park J. S., Woo J.-J., Liu D., Farkas E., OH S-O. \& HUR J.-S. (2016b): New lichen-forming and lichenicolous fungi from South Korea 2. - Acta Bot. Hung. 57(1-2):77-141. https://doi.org/10.1556/abot.57.2015.1-2.10

Kondratyuk S. Y., Lökös L., Halda J. P., Lee B. G., Liu D., Park J. S., Woo J.-J., Farkas E. $\&$ HUR J.-S. (2016c): First complex survey of the lichen flora of Ulleung-do Island (South Korea). - KSM News Letter 28(2): 66.

Kondratyuk S. Y., LöKös L., Kim J. A., Kondratiuk A. S., Jeong M.-H., Jang S. H., Oh S.-O., WANG X. Y. \& HUR J.-S. (2016d): Fauriea, a new genus of the lecanoroid caloplacoid lichens (Teloschistaceae, lichen-forming Ascomycetes). - Acta Bot. Hung. 58(3-4): 303-318. https://doi.org/10.1556/abot.58.2016.3-4.6

Kondratyuk S. Y., Lökös L., Halda J. P., Moniri M., Farkas E., Park J. S., Lee B. G., Oh S-O. $\&$ HUR J.-S. (2016e): New and noteworthy lichen-forming and lichenicolous fungi 4. - Acta Bot. Hung. 58(1-2): 75-136. https://doi.org/10.1556/034.58.2016.1-2.4

Kondratyuk S. Y., Lökös L., Halda J. P., Moniri M., Farkas E., Park J. S., Lee B. G., Liu D., Woo J.-J., Jayalal R. G. U., OH S.-O. \& Hur J.-S. (2016f): New and noteworthy lichenforming and lichenicolous fungi 5. - Acta Bot. Hung. 58(3-4): 78.

https://doi.org/ 10.1556/ABot.58.2016.3-4.7

Kondratyuk S. Y., Lőkös L., Park J. S., Jang S. H., Jeong M.-H. \& Hur J.-S. (2016g): New Aspicilia species from South Korea proved by molecular phylogeny with a key to the Eastern Asian aspicilioid lichens. - Studia bot. hung. 47(2): 227-249. https://doi.org/10.17110/studbot.2016.47.2.227

Kondratyuk S. Y., Lökös L., Halda J. P., Roux C., Upreti D. K., Schumm F., Mishra G. K., Nayaka S., Farkas E., Park J. S., Lee B. G., Liu D., Woo J.-J., Jayalal R. G. U., Oh S.-O. $\&$ HUR J.-S. (2017): New and noteworthy lichen-forming and lichenicolous fungi 6. - Acta Bot. Hung. 59(1-2): 137-260. https://doi.org/10.1556/034.59.2017.1-2.7

Kondratyuk S. Y., Lökös L., Halda J. P., Farkas E., Upreti D. K.; Thell A., Woo J.-J., OH S-O. \& HUR J.-S. (2018): New and noteworthy lichen-forming and lichenicolous fungi 7. Acta Bot. Hung. 60(1-2):115-184. https://doi.org/10.1556/034.60.2018.1-2.8

Kondratyuk S. Y., Halda J. P., Lökös L., Yamamoto Y., Popova L. P. \& Hur J.-S. (2019a): New and noteworthy lichen-forming and lichenicolous fungi 8. - Acta Bot. Hung. 61(1-2): 101-135. https://doi.org/10.1556/034.61.2019.1-2.8

Kondratyuk S. Y., Lökös L., Jang S.-H., HuR J.-S. \& Farkas E. (2019b): Phylogeny and taxonomy of Polyozosia, Sedelnikovaea and Verseghya of the Lecanoraceae (Lecanorales, lichenforming Ascomycota). - Acta Bot. Hung. 61(1-2):137-184.

https://doi.org/10.1556/034.61.2019.1-2.9 
Kondratyuk S. Y., Lökös L., Farkas E., Jang S.-H., Liu D., Halda J., Persson P.-E., Hansson M., Kärnefelt I., Thell A. \& HUR J.-S. (2019c): Three new genera of the Ramalinaceae (lichen-forming Ascomycota) and the phenomenon of presence of 'extraneous mycobiont DNA' in lichen associations. - Acta Bot. Hung. 61(3-4): 275-323.

https://doi.org/10.1556/034.61.2019.3-4.5

Kondratyuk S. Y., Lökös L., Farkas E., Jang S.-H., Liu D., Halda J., Persson P.-E., Hansson M., Kärnefelt I., Thell A., Fačkovcová Z., Yamamoto Y. \& Hur J.-S. (2019d): New and noteworthy lichen-forming and lichenicolous fungi 9. - Acta Bot. Hung. 61(3-4): 325-367. https://doi.org/10.1556/034.61.2019.3-4.6

Kondratyuk S., Lőkös L., Halda J., Lee B. G., Jang S.-H., Woo J.-J., Park J. S., Oh S.-O., HaN S.-K. \& Hur J.-S. (2019e): Arthonia dokdoensis and Rufoplaca toktoana - two new taxa from Dokdo Islands (South Korea). - Mycobiology, https://doi.org/10.1080/12298093.2019.1688074 (Published online: 14 Nov 2019).

KovÁcs D. \& LöKös L. (2016): Adatok a Mecsek hegység zuzmóflórájához. (Contributions to the lichen flora of the Mecsek Mts (South Hungary)). - Kitaibelia 21(1): 16-26. https://doi.org/10.17542/kit.21.16

Löкӧs L. (1983): Transzplantált zuzmóminták atomabszorpciós nehézfémanalizise Budapest területén. - Manuscript, MSc Thesis, ELTE, Budapest, 59 pp.

Löкös L. (1989): Studies on the lichens of the Tarna-vidék, NE-Hungary I. The lichen flora of Nagy-kő hill, near Bükkszenterzsébet. - Folia hist.-nat. Mus. Matr. 13: 61-62. (1988).

LöKös L. (2000): The lichen flora of the Villány Mts, SE Hungary. - Dunántúli Dolgozatok, Term. tud. Sor. 10: 13-35.

LöKös L. (2005): A Bacidia s. l. zuzmónemzetség hazai fajainak taxonómiai reviziója. - Manuscript, PhD Thesis, PTE, Növénytani Tanszék, Biológia Doktoriskola Pécs, 158 pp.

LöKös L. (2009): The lichen-forming fungi of the Aggtelek National Park (NE Hungary). - In: PAPP B. (ed): Flora of the Aggtelek National Park. Cryptogams. Hungarian Natural History Museum, Budapest, 109-174 pp.

Lökös L. (2010a): A Naszály zuzmóflórája. (The lichen flora of Mt Naszály (Hungary)). - In: PINTÉr B. \& TímÁr G. (eds): A Naszály természetrajza. Rosalia 5: 109-159.

Lökös L. (2010b): A Mecsek zuzmóflórája. (The lichen flora of the Mecsek Mts (SW Hungary).) Dunántúli dolgozatok (A), Természettudományi Sorozat 12: 20-41.

LőKÖs L. \& BALOGH L. (2016): Herbarium Piersianum 2. Piers Vilmos herbáriumának zuzmói a szombathelyi Savaria Múzeumban. (Herbarium Piersianum 2. Lichens from Vilmos Piers' herbarium in the Szombathely Savaria Museum). - Savaria, a Vas megyei Múzeumok Értesitöje 38: 7-49.

LöKös L. \& FARKAS E. (1998): Az Örség zuzmóflórájának alapvetése. (The lichen flora of Örség, Western Hungary). - Savaria, a Vas megyei Múzeumok Értesitóje 24(2): 127-160.

LöKös L. \& FARKAS E. (2000): Contributions to the knowledge of lichens of the forests along the Fekete-Körös, SE Hungary. - Studia bot. hung. 30-31: 69-78.

Löкös L. \& Tótн E. (1997): Red list of lichens of Hungary (a proposal). - In: Tótн E. \& HoRvÁTH R. (eds): Proceedings of the "Research, Conservation, Management" Conference, Aggtelek, Hungary, 1-5 May 1996, Volume I, pp. 337-343.

LöKös L. \& VerSEghy P. K. (2001): The lichen flora of the Kiskunság National Park and the southern part of the Danube-Tisza Interfluve. - In: Lökös L. \& RAJCZy M. (eds) (1999): The Flora of the Kiskunság National Park. Vol. 2. Cryptogams. Magyar Természettudományi Múzeum, Budapest, pp. 299-362.

LöKös L., Tóth Z. \& BALOGH L. (1997): A Köszegi-hegység zuzmóflórája. - Tilia 5: 7-91.

LöKös L., CrişAN F., Hur J-S., VARga N. \& FARKAS E. (2018): Enumeration of the lichen-forming and lichenicolous fungi of the Călimani Mountains (Eastern Carpathians, Romania). Studia bot. hung. 49(1): 5-40. https://doi.org/10.17110/studbot.2018.49.1.5 
Matus G., Szepesi J., Rózsa P., Lökös L., Varga N. \& Farkas E. (2017): Xanthoparmelia mougeotii (Parmeliaceae, lichenised Ascomycetes) new to the lichen flora of Hungary. Studia bot. hung. 48(1): 89-104. https://doi.org/10.17110/studbot.2017.48.1.89

MOLNÁR K. \& FARKAS E. (2010): Current results on biological activities of lichen secondary metabolites: a review. - Zeitschr.f. Naturforsch. 65c: 157-173.

https://doi.org/10.1515/znc-2010-3-401

Molnár K. \& FARKas E. (2011): Depsides and depsidones in populations of the lichen Hypogymnia physodes and its genetic diversity. - Ann. Bot. Fennici 48: 473-482. https://doi.org/10.5735/085.048.0605

MolnÁR K. \& LöKös L. (2007): Adatok az Upponyi-szoros zuzmóflórájához. (Contributions to the lichen flora of the Upponyi-szoros). - Folia nat.-hist. Mus. Matrensis 30: 25-34. (2006).

Molnár K., LöKös L., SChrett-Major Á. \& Farkas E. (2012): Molecular genetic analysis of Xanthoparmelia pulvinaris (Ascomycota, Lecanorales, Parmeliaceae). - Acta Bot. Hung. 54(1-2): 125-130. https://doi.org/10.1556/abot.54.2012.1-2.14

Moniri M. H., Gromakova A. B., Lökös L. \& Kondratyuk S. Y. (2017): New members of the Megasporaceae (Pertusariales, lichen-forming Ascomycota): Megaspora iranica spec. nova and Oxneriaria gen. Nova. - Acta Bot. Hung. 59(3-4): 343-370. https://doi.org/10.1556/034.59.2017.3-4.5

Oh S.-O., Park J.-S., Woo J.-J., Hur J.-S., Kondratyuk S., Lökös L. \& Halda J. (2019): A field guide to the Ulleungdo and Dokdo lichens. - Korea National Arboretum, Pocheon, 128 pp.

PAPp B., Lökös L., RajCzy M., Chatzinikolaki E. \& Damanakis M. (1999): Bryophytes and lichens of some phrygana and maquis stands of Crete (Greece). - Studia bot. hung. 29: 69-78.

Şenkardeşler A., Cansaran-Duman D., Lökös L. \& Ahti T. (2016): Cladonia trapezuntica (Cladoniaceae, lichenized Ascomycota): a robust morphotype of Pycnothelia papillaria. A taxonomic study with conservational survey. - Turkish J. Bot. 40(1): 104-111. https://doi.org/10.3906/bot-1403-49

ŞENKARDEŞLER A. \& LöKös L. (2010): Reassessment of lichen collections from Turkey deposited in the Hungarian Natural History Museum and examined by Ödön Szatala. - Acta Bot. Hung. 52(1-2): 197-215. https://doi.org/10.1556/abot.52.2010.1-2.e4

Şenkardeşler A., Lökös L. \& Calba O. F. (2011): Proposal to conserve the name Buellia subcanescens (Diploicia subcanescens) against B. leptina (lichenized Ascomycota, Caliciaceae). - Taxon 60(2): 587. https://doi.org/10.1002/tax.602028

ŞENKARDEŞLER A., LöKös L. \& FARKAS E. (2014): Lectotypification of names of lichen taxa described by Ödön Szatala. - Taxon 63(1): 139-145. https://doi.org/10.12705/631.9

SHIVARov V. \& Lökös L. (2015): New records and rare species of pyrenocarpous lichen-forming fungi from Bulgaria. - Studia bot. hung. 46: 111-118. https://doi.org/10.17110/StudBot.2015.46.2.111

Sinigla M., LöKös L., VARga N. \& FARKas E. (2014): Distribution of the lichen species Cetraria aculeata in Hungary. - Studia bot. hung. 45: 5-16.

https://doi.org/10.17110/studbot.2014.45.5

Sinigla M., LöKös L., VARga N. \& FAR Kas E. (2015): Distribution of the legally protected lichen species Cetraria islandica in Hungary. - Studia bot. hung. 46(1): 91-100. https://doi.org/10.17110/studbot.2015.46.1.91

Sinigla M., Lőкös L. \& VARga N. (2017): Ritka és védett zuzmófajok a Balaton-felvidék keleti részén. (Exploration of rare and protected lichen species in the eastern part of the Balaton Uplands). - Annls hist.-nat. Mus. natn. Hung. 108: 231-250. (2016). 
Sinigla M., Lökös L., Molnár K., Németh Cs. \& Farkas E. (2018): Distribution of the legally protected lichen species Solorina saccata in Hungary. - Studia bot. hung. 49(1): 47-70. https://doi.org/10.17110/studbot.2018.49.1.47

SOMLYAY L. \& LöKös L. (1997): Új és érdekes adatok a Zempléni-hegység flórájához. [New and interesting records to the flora of the Zemplén Mts]. - Kitaibelia 2(2): 241-242.

SZERDAHELYi T. \& LöKös L. (1992): Botanical collectings by the Hungarian Natural History Museum in Korea. A report on the collectings of the 2nd expedition. - Studia bot. hung. 23: $127-133$.

Szollát Gy. \& LöKös L. (1994): Botanical collecting trips in North Korea. - In: Sun B.-Y. (ed.): The flora and fauna of the Korean Peninsula and the conservation of its Biodiversity. Seoul, pp. 35-40.

SzURDoki E. (2019): Celebrating the 50th volume of Studia botanica hungarica. - Studia bot. bung. 50(1): 5-8. https://doi.org/10.17110/StudBot.2019.50.1.5

VARga N., LöKös L. \& FARKAS E. (2016): The lichen-forming and lichenicolous fungi of the Soroksár Botanical Garden (Szent István University, Budapest, Hungary). - Studia bot. hung. 47(1): 13-28. https://doi.org/10.17110/studbot.2016.47.1.13

VERSEGHY K. \& FARKAS E. (1984): Untersuchungen der Luftverunreinigung im Gebiet von Budapest mit Hilfe der Flechtenkartierung als Indikatoren. - Ann. Univ. Sci. Budapest., Sect. Biol. 24-26: 163-184.

Vondrák J., Khodosovtsev A., Lö Kös L. \& Merkulova O. (2010): The identity of type specimens in BP of some names in Caloplaca. - Mycotaxon 111: 241-250. https://doi.org/10.5248/111.241

VĚzdA A. \& FARKAS E. (1988): Neue foliicole Arten der Flechtengattung Dimerella Trevisan (Gyalectaceae) aus Tansania. - Folia Geobot. Phytotax. 23: 187-197. https://doi.org/10.1007/bf02853348

\section{List of genera new for science contributed by Edit Farkas and László Lőkös}

Coppinsidea S. Y. Kondr., E. Farkas et L. Lőkös

Coppinsiella S. Y. Kondr. \& Lőkös

Dijigiella S. Y. Kondr. et Lőkös

Fauriea S. Y. Kondr., Lőkös et Hur

Hosseusiella S. Y. Kondr., Lőkös, Kärnefelt et A. Thell

Ivanpisutia S. Y. Kondr., Lőkös et Hur

Jasonhuria S. Y. Kondr., Lőkös et S.-O. Oh

Kashiwadia S. Y. Kondr., Lőkös et Hur

Laundonia S. Y. Kondr., Lőkös et Hur

Lazarenkoiopsis S. Y. Kondr., Lőkös et Hur

Marfloraea S. Y. Kondr., Lőkös et Hur

Olegblumia S. Y. Kondr., Lőkös et Hur

Opeltia S. Y. Kondr. et Lőkös

Oxnerella S. Y. Kondr., Lőkös et Hur

Oxneriaria S. Y. Kondr. et Lőkös

Verseghya S. Y. Kondr., Lőkös et Hur.

Wolseleyidea S. Y. Kondr., E. Farkas et L. Lőkös 


\section{List of taxa new for science described by Edit Farkas and/or László Lőkös and co-authors}

Absconditella baegasanensis L. Lőkös, S. Y. Kondr. et J.-S. Hur Acarospora ulleungdoensis S. Y. Kondr., L. Lőkös et J.-S. Hur Agonimia ascendens S. Y. Kondr., L. Lőkös et J.-S. Hur Agonimia cavernicola S. Y. Kondr., L. Lőkös et J.-S. Hur Amandinea pseudomultispora S. Y. Kondr., L. Lőkös et J.-S. Hur Amandinea trassii S. Y. Kondr., L. Lőkös et J.-S. Hur Arthonia dokdoensis S. Y. Kondr., L. Lőkös, B. G. Lee, J.-J. Woo et J.-S. Hur Aspicilia geumodoensis S. Y. Kondr., L. Lőkös et J.-S. Hur Aspicilia pseudoabbasiana S. Y. Kondr., L. Lőkös et J.-S. Hur Aspicilia pseudovulcanica S. Y. Kondr., L. Lőkös et J.-S. Hur Aspicilia subepiglypta S. Y. Kondr., L. Lőkös et J.-S. Hur Aspicilia subgeographica S. Y. Kondr., L. Lőkös et J.-S. Hur Aspicilia subgoettweigensis S. Y. Kondr., L. Lőkös et J.-S. Hur Aspicilia submamillata S. Y. Kondr., L. Lőkös et J.-S. Hur Astroplaca loekoesiana S. Y. Kondr., E. Farkas, J.-J. Woo et J.-S. Hur Bacidina jasonhurii J. P. Halda, S. Y. Kondr. et L. Lőkös Bacidina simplex Farkas et Vězda Badimia vezdana Lücking, Farkas et Wirth Biatora ivanpisutii S. Y. Kondr., L. Lőkös et J.-S. Hur Buellia chujadoensis L. Lökös, S. Y. Kondr. et J.-S. Hur Buellia chujana Xin Y. Wang, S. Y. Kondr., L. Lőkös et J.-S. Hur Buellia ulleungdoensis S. Y. Kondr., L. Lőkös et J.-S. Hur Byssoloma absconditum Farkas et Vězda Byssoloma confusum Farkas et Vězda Calopadia erythrocephala Farkas, Elix et Flakus Caloplaca austrocoreana S. Y. Kondr., L. Lőkös et J.-S. Hur Caloplaca chujaensis S. Y. Kondr., L. Lőkös et J.-S. Hur Caloplaca ivanpisutii S. Y. Kondr., L. Lőkös et J.-S. Hur Caloplaca mandshuriaensis S. Y. Kondr., L. Lőkös et J.-S. Hur Caloplaca subconcilians S. Y. Kondr., L. Lökös et J.-S. Hur Candelariella hakulinenii S. Y. Kondr., L. Lőkös et J.-S. Hur Candelariella makarevichiae S. Y. Kondr., L. Lőkös et J.-S. Hur Catillaria ulleungdoensis S. Y. Kondr., L. Lőkös et J.-S. Hur, Coenogonium seychellense Farkas Coenogonium subdilucidum Farkas et Vězda Dimerella flavicans Vězda et Farkas Dimerella pocsii Vězda et Farkas Dimerella subdilucida Vězda et Farkas Dimerella subfallaciosa Vězda et Farkas Dimerella tanzanica Vězda et Farkas Dimerella usambarensis Vězda et Farkas Endococcus xanthoparmeliae Y. Joshi, S. Y. Kondr., L. Lőkös et J.-S. Hur Fauriea jejuensis S. Y. Kondr., L. Lőkös et J.-S. Hur Fellhanera chejuensis L. Lőkös, S. Y. Kondr. et J.-S. Hur Fellhanera maritima S. Y. Kondr., L. Lőkös et J.-S. Hur 
Fuscidea coreana S. Y. Kondr., L. Lőkös et J.-S. Hur

Fuscidea extremorientalis S. Y. Kondr., L. Lőkös et J.-S. Hur Gyalecta ulleungdoensis S. Y. Kondr., L. Lőkös et J.-S. Hur Gyalectidium palmicola Farkas et Vězda Gyalidea austrocoreana S. Y. Kondr., L. Lőkös et J.-S. Hur Gyalidea koreana J.P. Halda, S. Y. Kondr., L. Lőkös et J.-S. Hur Gyalidea pisutii J.P. Halda, S. Y. Kondr., L. Lőkös et J.-S. Hur Gyalidea poeltii S. Y. Kondr., L. Lőkös, J. P. Halda et J.-S. Hur Gyalidea ropalosporoides S. Y. Kondr., L. Lőkös et J.-S. Hur Gyalidea vezdae S. Y. Kondr., L. Lőkös, J. P. Halda et J.-S. Hur Hafellia extremorientalis S. Y. Kondr., L. Lőkös et J.-S. Hur Hafellia pseudosubnexa S. Y. Kondr., L. Lőkös et J.-S. Hur Halecania subalpivaga S. Y. Kondr., L. Lőkös et J.-S. Hur Hanstrassia jaeseounhurii S. Y. Kondr., C. H. Park et L. Lőkös Hosseusiella gallowayana S. Y. Kondr., L. Lőkös, J.-S. Hur, Kärnefelt et A. Thell Huriella pohangensis S. Y. Kondr., L. Lőkös et J.-S. Hur Ivanpisutia oxneri S. Y. Kondr., L. Lőkös et J.-S. Hur Keratosphaera antoniana Flakus, Farkas et Lücking Lecanactis subdilleniana S. Y. Kondr., L. Lőkös et J.-S. Hur Lecania chirisanensis S. Y. Kondr., L. Lőkös et J.-S. Hur Lecania coreana S. Y. Kondr., L. Lőkös et J.-S. Hur Lecania rinodinoides S. Y. Kondr., L. Lőkös et J.-S. Hur Lecanora lojkahugoi S. Y. Kondr., L. Lőkös et J.-S. Hur Lecanora orlovii S. Y. Kondr. et L. Lőkös

Lecanora pseudosambuci S. Y. Kondr., L. Lőkös et J.-S. Hur Lecanora ussuriensis S. Y. Kondr., L. Lőkös et J.-S. Hur Lecidella mandshurica S. Y. Kondr., L. Lőkös et J.-S. Hur Lichenochora hypanica S. Y. Kondr., L. Lőkös et J.-S. Hur Lichenochora makareviczae S. Y. Kondr., L. Lőkös et J.-S. Hur Lichenostigma epiporpidiae S. Y. Kondr., L. Lőkös et J.-S. Hur Lichenostigma heterodermiae S. Y. Kondr., L. Lőkös et J.-S. Hur Lyromma coronatum Flakus et Farkas Lyromma multisetulatum Flakus et Farkas Macentina borbidii Farkas et Vězda Macentina pocsii Farkas et Vězda Maronella coreana S. Y. Kondr., L. Lőkös et J.-S. Hur Melanophloea coreana S. Y. Kondr., L. Lőkös et J.-S. Hur Micarea coreana Lőkös, S. Y. Kondr. et J.-S. Hur Nectriopsis gangwondoensis S. Y. Kondr., L. Lőkös et J.-S. Hur Nectriopsis verseghyklarae S. Y. Kondr., L. Lőkös et J.-S. Hur Ochrolechia yurii S. Y. Kondr., L. Lőkös, S.-O. Oh et J.-S. Hur Olegblumia demissa S. Y. Kondr., L. Lőkös, J. Kim, A. S. Kondr., S.-O. Oh et J.-S. Hur Opegrapha briancoppinsii S. Y. Kondr., L. Lőkös et J.-S. Hur Opegrapha ulleungdoensis S. Y. Kondr., L. Lökös et J.-S. Hur Opegrapha verseghyklarae S. Y. Kondr., L. Lőkös et J.-S. Hur Orientophila dodongana S. Y. Kondr., L. Lőkös et J.-S. Hur Orientophila dodongensis S. Y. Kondr., L. Lökös et J.-S. Hur Orientophila fauriei S. Y. Kondr., L. Lőkös et J.-S. Hur 
Orientophila imjadoensis S. Y. Kondr., L. Lőkös et J.-S. Hur Orientophila incheonensis S. Y. Kondr., L. Lőkös et J.-S. Hur Oxnerella safavidiorum S. Y. Kondr., B. Zarei-Darki, L. Lőkös et J.-S. Hur Oxneriopsis taehaensis S. Y. Kondr., L. Lőkös et J.-S. Hur Phaeophyscia esslingeri S. Y. Kondr., L. Lőkös, J.-J. Woo et J.-S. Hur Phoma heterodermiae S. Y. Kondr., L. Lőkös et J.-S. Hur Phyllopsora loekoesii S. Y. Kondr., E. Farkas, S.-O. Oh et J.-S. Hur Physcia orientostellaris S. Y. Kondr., L. Lőkös et J.-S. Hur Physcia ucrainica S. Y. Kondr., L. Lőkös et J.-S. Hur Placynthiella hurii S. Y. Kondr. et L. Lőkös Polycoccum clauderouxii S. Y. Kondr., L. Lőkös et J.-S. Hur Polysporina golubkovae S. Y. Kondr., L. Lőkös, J. S. Park et J.-S. Hur Porina sphaerocephaloides Farkas Porina ulleungdoensis S. Y. Kondr., L. Lőkös, J. P. Halda et J.-S. Hur Porpidia ulleungdoensis S. Y. Kond., L. Lőkös et J. P. Halda Protoparmeliopsis kopachevska S. Y. Kondr., L. Lőkös et J.-S. Hur Psoroglaena chirisanensis L. Lőkös, S. Y. Kondr. et J.-S. Hur Psoroglaena coreana S. Y. Kondr., L. Lökös et J.-S. Hur Psoroglaena gangwondoensis S. Y. Kondr., L. Lőkös, J.-J. Woo et J.-S. Hur Psoroglaena sunchonensis S. Y. Kondr., L. Lőkös et J.-S. Hur Psorotichia gyelnikii S. Y. Kondr., L. Lőkös et J.-S. Hur Pyrenidium ucrainicum S. Y. Kondr., L. Lőkös et J.-S. Hur Pyrenopsis cavernicola S. Y. Kondr., L. Lőkös et J.-S. Hur Pyrenopsis chejudoensis L. Lökös, S. Y. Kondr. et J.-S. Hur Rinodina oxneriana S. Y. Kondr., L. Lőkös et J.-S. Hur Ropalospora chirisanensis S. Y. Kondr., L. Lőkös et J.-S. Hur Roselliniopsis phaeophysciae S. Y. Kondr., L. Lőkös et J.-S. Hur Rufoplaca kaernefeltiana S. Y. Kondr., L. Lőkös et J.-S. Hur Rufoplaca toktoana S. Y. Kondr., L. Lőkös et J.-S. Hur Rufoplaca ulleungensis S. Y. Kondr., L. Lőkös et J.-S. Hur Sarcogyne ulleungdoensis S. Y. Kondr., L. Lőkös et J.-S. Hur Scoliciosporum jasonhurii S. Y. Kondr., S.-O. Oh et L. Lőkös Staurothele oxneri S. Y. Kondr., L. Lőkös et J.-S. Hur Stigmidium coarctatae S. Y. Kondr., L. Lőkös et J.-S. Hur Thelocarpon ulleungdoense S. Y. Kondr., L. Lőkös, J.-J. Woo et J.-S. Hur Thelopsis chirisanensis Lőkös, S. Y. Kondr. et J.-S. Hur Thelopsis gangwondoensis S. Y. Kondr., L. Lőkös, J.-J. Woo et J.-S. Hur Toninia poeltiana S. Y. Kondr., Lőkös et J.-S. Hur Topelia jasonhurii L. Lőkös, E. Farkas et S. Y. Kondr Trapelia coreana S. Y. Kondr., L. Lőkös et J.-S. Hur Trichonectria calopadiicola Farkas et Flakus Unguiculariopsis helmutii S. Y. Kondr., L. Lőkös et J.-S. Hur Verseghya klarae S. Y. Kondr., L. Lőkös et J.-S. Hur Vezdaea poeltiana S. Y. Kondr., L. Lőkös, J. P. Halda et J.-S. Hur Yoshimuria ivanpisutiana S. Y. Kondr., L. Lőkös et J.-S. Hur Yoshimuria seokpoensis S. Y. Kondr., L. Lőkös et J.-S. Hur 


\section{New names (nom. n.) and new combinations of taxa described by Edit Farkas} and/or László Lőkös and co-authors

Aspicilia abbasiana S. Y. Kondr., L. Lőkös, Ismayil et Guo, nom.n. Athallia inconnexa (Nyl.) S. Y. Kondr. et L. Lőkös

Bacidina cinnamomea (Krempelhuber) Farkas

Bacidina clauzadei (Sérus. et Lambinon) Farkas

Biatora pseudosambuci (S. Y. Kondr., L. Lőkös et J.-S. Hur) S. Y. Kondr., L. Lőkös et J.-S. Hur

Brasilicia dimerelloides (Vězda) Farkas

Brasilicia foliicola (Vězda) Farkas

Brasilicia ituriensis (Vězda) Farkas

Brasilicia olivaceorufa (Vainio) Farkas

Brasilicia subsimilis (Vězda) Farkas

Buellia extremoorientalis (S. Y. Kondr., L. Lőkös et J.-S. Hur) S. Y. Kondr., L. Lőkös et J.-S. Hur

Buellia pseudosubnexa (S. Y. Kondr., L. Lőkös et J.-S. Hur) S. Y. Kondr., L. Lőkös et J.-S. Hur

Calogaya safavidiorum (S. Y. Kondr.) S. Y. Kondr. et L. Lőkös

Coppinsidea alba (Coppins et Vězda) S. Y. Kondr., E. Farkas et L. Lőkös

Coppinsidea aphana (Nyl.) S. Y. Kondr., E. Farkas et L. Lőkös

Coppinsidea croatica (Zahlbr.) S. Y. Kondr., E. Farkas et L. Lőkös

Coppinsidea fuscoviridis (Anzi) S. Y. Kondr., E. Farkas et L. Lőkös

Coppinsidea pallens (Kullh.) S. Y. Kondr., E. Farkas et L. Lőkös

Coppinsidea ropalosporoides (S. Y. Kondr., L. Lőkös et J.-S. Hur) S. Y. Kondr., E. Farkas et L. Lőkös

Coppinsidea scotinodes (Nyl.) S. Y. Kondr., E. Farkas et L. Lőkös

Coppinsidea sphaerella (Hedl.) S. Y. Kondr., E. Farkas et L. Lőkös

Coppinsidea vainioana S. Y. Kondr., E. Farkas et L. Lőkös, nom. n.

Coppinsiella orbicularis (M. Haji Moniri, Vondrák et Malíček) S. Y. Kondr. et L. Lőkös

Coppinsiella substerilis (Vondrák, Palice et van den Boom) S. Y. Kondr. et L. Lőkös

Coppinsiella ulcerosa (Coppins et P. James) S. Y. Kondr. et L. Lőkös

Dibaeis yurii (S. Y. Kondr., L. Lőkös, S.-O. Oh et J.-S. Hur) S. Y. Kondr., L. Lőkös et J.-S. Hur

Fauriea chujaensis (S. Y. Kondr., L. Lőkös et J.-S. Hur) S. Y. Kondr., 1. Lőkös, J. Kim, A. S. Kondr.,

S.-O. Oh et J.-S. Hur

Fauriea tabidella (Nyl.) S. Y. Kondr., Lőkös et J.-S. Hur

Fellhanera cateilea (Vain.) Farkas

Glaucomaria bicincta (Ramond) S. Y. Kondr., L. Lőkös et Farkas

Glaucomaria carpinea (L.) S. Y. Kondr., L. Lőkös et Farkas

Glaucomaria leptyrodes (G. B. F. Nilsson) S. Y. Kondr., L. Lőkös et Farkas

Glaucomaria lojkaeana (Szatala) S. Y. Kondr., L. Lőkös et Farkas

Glaucomaria subcarpinea (Szatala) S. Y. Kondr., L. Lőkös et Farkas

Glaucomaria sulphurea (Hoffm.) S. Y. Kondr., L. Lőkös et Farkas

Glaucomaria swartzii (Ach.) S. Y. Kondr., L. Lőkös et Farkas

Glaucomaria swartzii subsp._caulescens (J. Steiner) S. Y. Kondr., L. Lőkös et Farkas

Glaucomaria swartzii subsp. nylanderi (Räsänen) S. Y. Kondr., L. Lőkös et Farkas

Hosseusiella chilensis (Kärnefelt, S. Y. Kondr., Frödén et Arup) S. Y. Kondr., L. Lőkös, Kärnefelt et A. Thell

Hosseusiella pergracilis (Zahlbr.) S. Y. Kondr., L. Lőkös et A. Thell

Jasonhuria bogilana (Y. Joshi et Hur) S. Y. Kondr., L. Lőkös, J. Kim, A. S. Kondr. et S.-O. Oh 
Kashiwadia orientalis (Kashiw.) S. Y. Kondr., L. Lőkös et J.-S. Hur Laundonia flavovirescens (Wulfen) S. Y. Kondr., L. Lőkös et Hur Laundonia persimilis (Wetmore) S. Y. Kondr., L. Lőkös et Hur Lazarenkoella persica (J. Steiner) S. Y. Kondr. et L. Lőkös Lazarenkoella polycarpoides (J. Steiner) S. Y. Kondr. et L. Lőkös Lazarenkoiopsis ussuriensis (Oxner, S. Y. Kondr. et Elix) S. Y. Kondr., L. Lőkös et Hur Lecanoropsis anopta (Nyl.) S. Y. Kondr., L. Lőkös et Farkas Lecanoropsis macleanii (C. W. Dodge) S. Y. Kondr., L. Lőkös et Farkas Marfloraea albescens (Huds.) S. Y. Kondr., L. Lőkös et Hur Marfloraea amara (Ach.) S. Y. Kondr., L. Lőkös et Hur Marfloraea aspergilla (Ach.) S. Y. Kondr., L. Lökös et Hur Marfloraea corallina (L.) S. Y. Kondr., L. Lökös et Hur Marfloraea corallophora (Vain.) S. Y. Kondr., L. Lőkös et Hur Marfloraea erythrella (Müll. Arg.) S. Y. Kondr., L. Lőkös et Hur Marfloraea excludens (Nyl.) S. Y. Kondr., L. Lőkös et Hur Marfloraea mammosa (Harm.) S. Y. Kondr., L. Lőkös et Hur Marfloraea ophthalmiza (Nyl.) S. Y. Kondr., L. Lőkös et Hur Marfloraea panyrga (Ach.) S. Y. Kondr., L. Lőkös et Hur Marfloraea pulvinata (Erichsen) S. Y. Kondr., L. Lőkös et Hur Marfloraea scaberula (A.W. Archer) S. Y. Kondr., L. Lőkös et Hur Marfloraea subventosa (Malme) S. Y. Kondr., L. Lőkös et Hur Myrionora australis (Rodr. Flakus et Printzen) S. Y. Kondr., L. Lőkös et Hur Niesslia coarctatae (S. Y. Kondr., Lőkös et Hur) S. Y. Kondr., L. Lőkös et Hur Ochrolechia dactylina (Ach.) S. Y. Kondr., L. Lőkös et Hur Omphalodina chrysoleuca (Sm.) S. Y. Kondr., L. Lőkös et Farkas Omphalodina huashanensis (J. C. Wei) S. Y. Kondr., L. Lökös et Farkas Omphalodina opiniconensis (Brodo) S. Y. Kondr., L. Lőkös et Farkas Omphalodina phaedrophthalma (Poelt) S. Y. Kondr., L. Lőkös et Farkas Omphalodina pseudistera (Nyl.) S. Y. Kondr., L. Lőkös et Farkas Opeltia arizonica (H. Magn.) S. Y. Kondr. et L. Lőkös Opeltia juniperina (Tomin) S. Y. Kondr. et L. Lőkös Opeltia neobaltistanica (S. Y. Kondr. et Hur) S. Y. Kondr. et L. Lőkös Orientophila chejuensis (S. Y. Kondr. et Hur) S. Y. Kondr., L. Lőkös et Hur Orientophila diffluens (Hue) S. Y. Kondr., L. Lőkös et Hur Orientophila leucerythrella (Nyl.) S. Y. Kondr., L. Lőkös et Hur Oxneriaria dendroplaca (H. Magn.) S. Y. Kondr. et L. Lőkös Oxneriaria haeyrenii (H. Magn.) S. Y. Kondr. et L. Lőkös Oxneriaria mashiginensis (Zahlbr.) S. Y. Kondr. et L. Lőkös Oxneriaria nikrapensis (Darb.) S. Y. Kondr. et L. Lőkös Oxneriaria permutata (Zahlbr.) S. Y. Kondr. et L. Lőkös Oxneriaria rivulicola (H. Magn.) S. Y. Kondr. et L. Lőkös Oxneriaria supertegens (Arnold) S. Y. Kondr. et L. Lőkös Oxneriaria verruculosa (Kremp.) S. Y. Kondr. et L. Lőkös Oxneriaria virginea (Hue) S. Y. Kondr. et L. Lőkös Palicella anakeestiicola (Lendemer et E. Tripp) S. Y. Kondr., L. Lőkös et Farkas Polyozosia albescens (Hoffm.) S. Y. Kondr., L. Lőkös et Farkas 
Polyozosia andrewii (B. de Lesd.) S. Y. Kondr., L. Lőkös et Farkas

Polyozosia contractula (Nyl.) S. Y. Kondr., L. Lőkös et Farkas

Polyozosia crenulata (Ach.) S. Y. Kondr., L. Lőkös et Farkas

Polyozosia dispersa (Pers.) S. Y. Kondr., L. Lőkös et Farkas

Polyozosia hagenii (Ach.) S. Y. Kondr., L. Lőkös et Farkas

Polyozosia perpruinosa Fröberg ex S. Y. Kondr., L. Lőkös et Farkas

Polyozosia populicola (DC.) S. Y. Kondr., L. Lőkös et Farkas

Polyozosia pruinosa (Chaub.) S. Y. Kondr., L. Lőkös et Farkas

Polyozosia reuteri (Schaer.) S. Y. Kondr., L. Lőkös et Farkas

Polyozosia sambuci (Pers.) S. Y. Kondr., L. Lőkös et Farkas

Polyozosia semipallida (H. Magn.) S. Y. Kondr., L. Lőkös et Farkas

Polyozosia straminea (Ach.) S. Y. Kondr., L. Lőkös et Farkas

Polyozosia thuleana (Poelt) S. Y. Kondr., L. Lőkös et Farkas

Pseudocyphellaria epiflavoides (Gyeln.) Lücking, Farkas et L. Lőkös

Pyrenodesmia duplicata (Vain.) S. Y. Kondr., L. Lőkös et Hur

Rimularia geumodoensis (S. Y. Kondr., L. Lőkös et Hur) S. Y. Kondr., L. Lőkös et Hur

Sedelnikovaea marginalis (Hasse) S. Y. Kondr., L. Lőkös et Farkas

Sedelnikovaea subdiscrepans (Nyl.) S. Y. Kondr., L. Lökös et Farkas

Squamulea micromera (Hue) S. Y. Kondr., L. Lőkös et Hur,

Straminella bullata (Follmann et A. Crespo) S. Y. Kondr., L. Lőkös et Farkas

Straminella burgaziae (I. Martínez et Aragón) S. Y. Kondr., L. Lőkös et Farkas

Straminella conizaeoides (Nyl. ex Cromb.) S. Y. Kondr., L. Lőkös et Farkas

Straminella densa (Śliwa et Wetmore) S. Y. Kondr., L. Lőkös et Farkas

Straminella maheui (Hue) S. Y. Kondr., L. Lőkös et Farkas

Straminella varia (Hoffm.) S. Y. Kondr., L. Lőkös et Farkas

Thamnolecania racovitzae (Vain.) S. Y. Kondr., L. Lökös et Hur

Verseghya thysanophora (R. C. Harris) S. Y. Kondr., L. Lőkös, Farkas et Hur

Wolseleyidea africana (Timdal et Krog) S. Y. Kondr., Farkas et L. Lőkös

Wolseleyidea byssiseda (Nyl. ex Hue) S. Y. Kondr., Farkas et L. Lőkös

Wolseleyidea canoumbrina (Vain.) S. Y. Kondr., Farkas et L. Lőkös

Wolseleyidea furfurella (Kistenich et Timdal) S. Y. Kondr., Farkas et L. Lőkös

Wolseleyidea ochroxantha (Nyl.) S. Y. Kondr., Farkas et L. Lőkös

Wolseleyidea swinscowii (Timdal et Krog) S. Y. Kondr., Farkas et L. Lőkös

\section{List of taxa named after Edit Farkas and László Lőkös (new taxa and new com- binations) including two new genera named after László:}

Loekoesia S. Y. Kondr., S.-O. Oh et Hur

Loekoeslaszloa S. Y. Kondr. et Hur

Agonimia loekoesii S. Y. Kondr., J. Halda et J.-S. Hur

Astroplaca loekoesiana S. Y. Kondr., E. Farkas, J.-J. Woo et Hur [= Placolecis loekoesiana (S. Y. Kondr.,

Farkas, J.-J. Woo et Hur) An C. Yin]

Bacidina loekoesiana S. Y. Kondr. et Hur

Biatora loekoesiana S. Y. Kondr. et Hur

Byssoloma farkasii Sipman 
Calopadia editae Vězda ex Chaves et Lücking

Caloplaca loekoesii S. Y. Kondr. et J.-S. Hur [= Orientophila loekoesii (S. Y. Kondr. et Hur) Arup, Søchting et Frödén]

Cryptothecia farkasiae Lücking [= Amazonomyces farkasiae (Lücking) Lücking, Sérus. et G. Thor] Flavoplaca laszloana S. Y. Kondr. et Hur

Huriella loekoesiana S. Y. Kondr. et D. Upreti

Lecanora loekoesii Y. Joshi, L. Lü et Hur

Lecanora subloekoesii Z. T. Zhao et L. Lü

Phyllopsora loekoesii S. Y. Kondr., E. Farkas, S.-O. Oh et Hur

Thelopsis loekoesii S. Y. Kondr., J. Halda et Hur

Topelia loekoesiana S. Y. Kondr., J.-J. Woo et Hur 